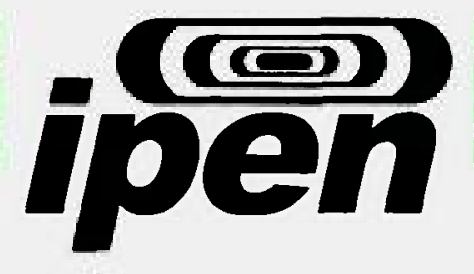

AUTARQUIA ASSOCIADA À UNIVERSIDADE DE SÃO PAULO

\title{
AVALIAÇÃO DO DANO RADIOINDUZIDO, CAPACIDADE DE REPARO E MORTE CELULAR EM CÉLULAS HUMANAS \\ TUMORAIS (T-47D e MCF-7) E NÃO TUMORAIS (MCF-10) DE MAMA
}

FLÁVIA GOMES SILVA VALGÔDE

Dissertação apresentada como parte dos requisitos para obtenção do Grau de Mestre em Ciências na Área de Tecnologia Nuclear - Aplicações.

Orientadora:

Dra. Kayo Okazaki

São Paulo

2008 
INSTITUTO DE PESQUISAS ENERGÉTICAS E NUCLEARES Autarquia associada à Universidade de São Paulo

AVALIAÇÃO DO DANO RADIOINDUZIDO, CAPACIDADE DE REPARO E MORTE CELULAR EM CÉLULAS HUMANAS TUMORAIS (T-47D E MCF-7) E NÃO TUMORAIS (MCF-10) DE MAMA

FLÁVIA GOMES SILVA VALGÔDE

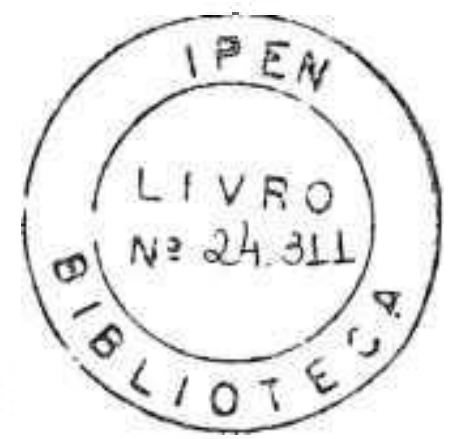

Dissertação apresentada como parte dos requisitos para obtenção do grau de Mestre em Ciências na Área de Tecnologia Nuclear Aplicações.

Orientadora:

Dra. Kayo Okazaki

\section{São Paulo}

2008 
'O homem não é senão o seu projeto, e só existe na medida em que se reafiza" Jean-Paul Sartre. 
Para melhor família do mundo.

À minha mãe Maria e ao meu pai Serafim, por estarem sempre do meu lado, por acreditarem em mim, pelo amor infinito e pela confiança que sempre me dedicaram.

$\mathcal{E}$ aos meus pontinfos de Luz, Fabiana e Fermanda, pelo amor, carinfo, preocupação, apoio e incentivo. 


\section{AGRADECIMENTOS}

Primeiro gostaria de agradecer a Deus, por essa magnífica oportunidade e por conseguir concluí-la.

À Dra Kayo Okazaki, pelos ensinamentos, confiança, dedicação, profissionalismo e paciência com que me orientou, e pelo carinho e grande amizade.

À Dra Márcia Augusta da Silva, por sua imensa colaboração, enorme paciência e maravilhosa amizade.

À Miriam Fussae Suzuki, por toda ajuda prestada e por quem tenho uma grande admiração como pessoa e como profissional.

Ao Dr. Paolo Bartolini, Dr. Carlos Roberto Jorge Soares e a Dra Maria Teresa Ribela por contribuirem diretamente com este trabalho.

Ao Dr. Eric Ueda, pelos conselhos, favores, amizade e apoio em todos os momentos.

A todo o Centro de Biotecnologia, Dra Cibele, Dr. João Ezequiel, Dr. Herbert, Nélio, José Maria, Junqueira, Suely, Edna, Néia e Dirce.

As flores do meu jardim, Beatriz, Cristiane, Daniele, Fernanda, Geyza, Janaina, Rosa e Susana pelo companheirismo, cumplicidade e amizade.

À Beth e ao Carlos, por sempre estarem dispostos a me ajudar nas irradiaçöes.

Aos amigos do Instituto Butantan, Vanessa, Alessandro, Lenita e Alex por toda ajuda e apoio.

A toda minha família, em especial a minha vó Inês, ao meu tio Antonio, a minha tia Edna e ao meu tio Marcos pelo amor incondicional, por sofrerem junto comigo, pelo exemplo de força e coragem que tenho o maior orgulho em seguir.

As minhas irmãs do coração, Cláudia, Natália, Renata e Tais por participarem com todo amor e carinho das 24 horas do meu dia, todos os dias, na alegria e na tristeza, na saúde e na doença.

À Camila Araujo, Camila Pellicciotti, Caroline Dezontini, Cristina José, Danilo Puzzi, Felipe Sene de Oliveira Lino, Gianlucca Nicastro, Julia Porto Aranha, Juliana Machado Simões, Larissa Leme Meyer, Lucas Samuel Zamora, Luisa Bega de Paiva, Maria Aparecida de Araujo (in memorian), Marina Sancet, Marisa Porto Aranha, Mayra Beraldo Andozia, Rafael Sanfurgo, Roberta Montero Costa, Rodrigo Simões, Ronaldo Anunciação, Sanara Penteado, Thiago Henrique Cruz e Tiago Porto Aranha que me cederam carinho, tempo, palavras e conselhos. 


\title{
AVALIAÇÃO DO DANO RADIOINDUZIDO, CAPACIDADE DE REPARO E MORTE CELULAR EM CÉLULAS HUMANAS TUMORAIS (T-47D e MCF-7) E NÄO TUMORAIS (MCF-10) DE MAMA
}

\author{
Flávia Gomes Silva Valgôde
}

\section{RESUMO}

Câncer de mama é considerado uma das malignidades mais comuns que acometem as mulheres, representando cerca de uma em cada três de todas as neoplasias femininas. Aproximadamente, $90 \%$ dos casos de câncer de mama são esporádicos, atribuiveis aos eventos somáticos e cerca de $10 \%$ estão associados com a história familial e destes somente $4-5 \%$ são decorrentes de fatores hereditários. Em clínica, a radiação ionizante é a principal ferramenta utilizada no controle do crescimento tumoral, além da intervenção cirúrgica e quimioterapia. Há, no entanto, poucas informações no que diz respeito a resposta celular frente à ação da radiação ionizante em células-alvo, isto é, em linhagens celulares originárias de câncer de mama. $O$ presente estudo foi proposto para analisar a radiossensibilidade de células humanas tumorais (T-47D e MCF-7) e não tumorais (MCF-10), originárias de mama, submetidas a várias doses $(0,5$ a 30 Gy) de radiação y de ${ }^{60} \mathrm{Co}(0,72-1,50 \mathrm{~Gy} / \mathrm{min})$. Para tanto, foram utilizados como parâmetros de radiossensibilidade, dano radioinduzido ao DNA, capacidade de reparo e morte celular, por meio das técnicas do micronúcleo, eletroforese de microgel (teste do cometa) e viabilidade celular. Os dados obtidos mostraram que as linhagens tumorais (T-47D e MCF-7) foram mais radiossensiveis que a linhagem não tumoral (MCF-10) para todos os testes utilizados. A linhagem T-47D foi a que apresentou uma maior quantidade de dano radioinduzido, um ciclo celular mais acelerado e uma maior taxa de morte celular. As três linhagens celulares apresentaram uma capacidade de reparo relativamente eficiente, tendo em vista que uma hora após a irradiação, todas elas exibiram uma redução considerável de dano radioinduzido quando comparadas logo após as exposições. Os testes empregados mostraram ser seguros, sensiveis e reprodutiveis e permitiram quantificar e avaliar danos induzidos ao DNA, capacidade de reparo e morte celular, nas três linhagens originárias de mama humana. 


\title{
EVALUATION OF THE RADIOINDUCED DAMAGE, REPAIR CAPACITY AND CELL DEATH ON HUMAN TUMORIGENIC (T-47D AND MCF-7) AND NONTUMORIGENIC (MCF-10) CELL LINES OF BREAST
}

\author{
Flávia Gomes Silva Valgôde
}

\section{ABSTRACT}

Breast cancer is one of the most common malignancies that account women, representing about one in three of all female neoplasm. Approximately, $90 \%$ of cases are considered sporadic, attributed to somatic events and about $10 \%$ have a family history and this only $4-5 \%$ is decurrent of hereditary factors. In the clinic, ionizing radiation is a major tool utilized in the control of tumour growth, besides surgery and chemotherapy. There is, however, little information concerning cellular response to the action of ionizing radiation in the target cells, i.e., cell lines originating from breast cancer. The present study proposed to analyze the radiosensitivity of the human tumorigenic (T-47D and MCF-7) and nontumorigenic (MCF-10) cell lines, originating from breast and submitted to various doses ( 0.5 to $30 \mathrm{~Gy}$ ) of ${ }^{60} \mathrm{Co}$ rays $(0.72-1.50 \mathrm{~Gy} / \mathrm{min})$. For this purpose, DNA radioinduced damage, repair capacity and cell death were utilized as parameters of radiosensitivity by micronúcleus, single cell gel electrophoresis (Comet assay) and cell viability techniques. The data obtained showed that tumorigenic cell lines were more radiosensitive than nontumorigenic breast cells in all assays here utilized. The T-47D cell line was presenting the highest amount of radioinduced damage, a more accelerated proliferation rate and a higher rate of cell death. The three cell lines presented a relatively efficient repair capacity, since one hour after the irradiation all of them showed a considerable reduction of radioinduced damage. The techniques employed showed to be secure, sensitive and reproducible, allowing to quantify and evaluate DNA damage, repair capacity and cell death in the three human breast cell lines. 


\section{SUMÁRIO}

Página

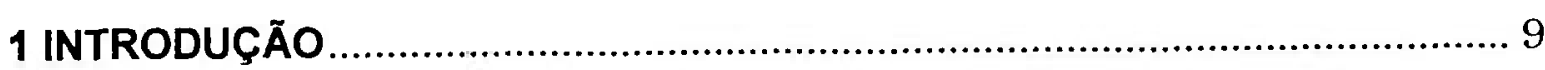

1.1 Considerações gerais sobre o câncer de mama...............................................11

1.2 Considerações gerais sobre radiação ionizante ........................................... 15

1.3 Considerações gerais sobre reparo celular.................................................. 17

1.3.1 Reparo por ligação das extremidades não-homólogas (NHEJ) .................... 18

1.3.2 Reparo por recombinação homóloga (HR) ............................................... 19

1.4 Considerações gerais sobre técnicas citogenéticas e bioquimicas ................ 20

1.5 Considerações gerais sobre suscetibilidade de pacientes com câncer de

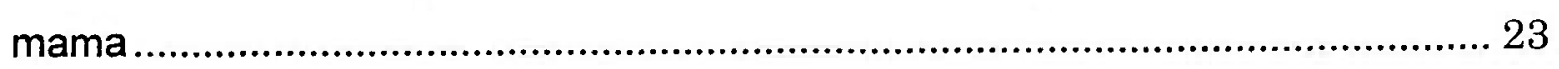

2 OBJETIVO

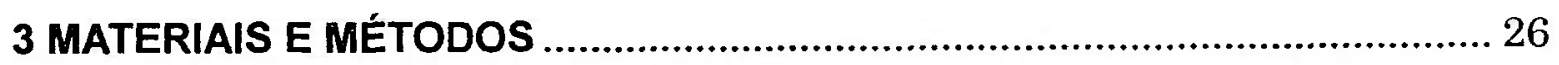

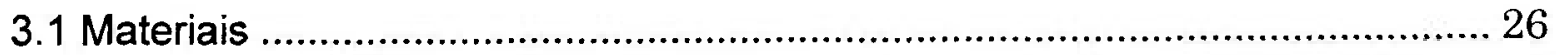

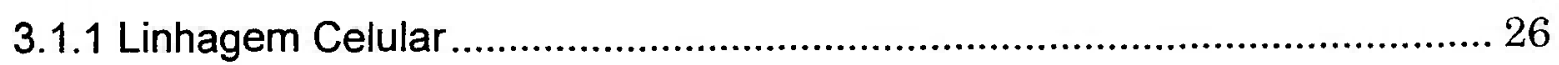

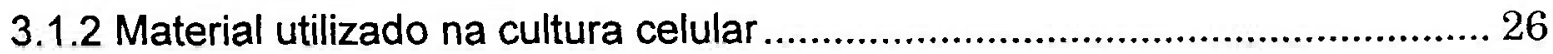

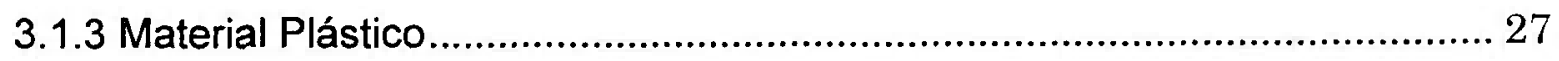

3.1.4 Reagentes utilizados no teste do micronúcleo ........................................ 27

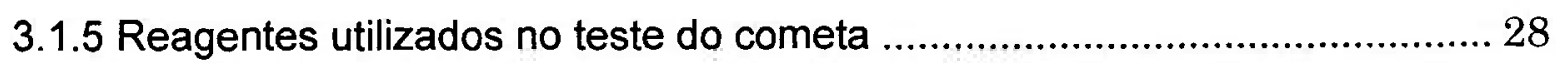

3.1.6 Reagentes utilizados no ensaio de viabilidade celular ............................... 28

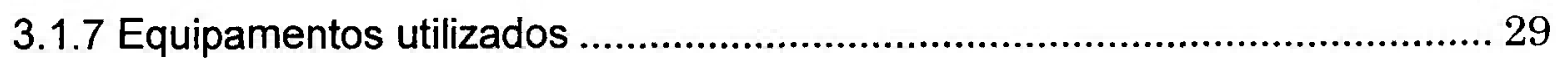

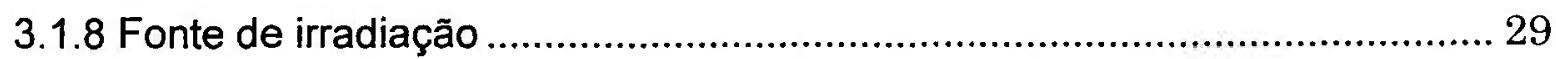

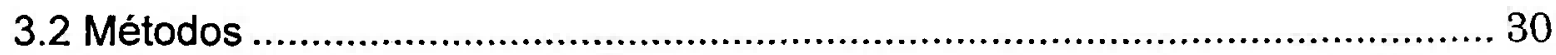

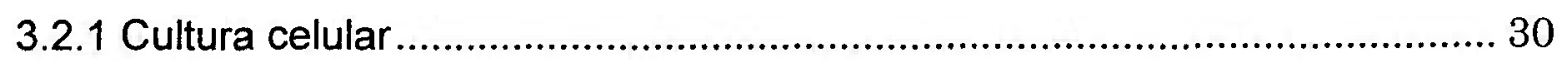

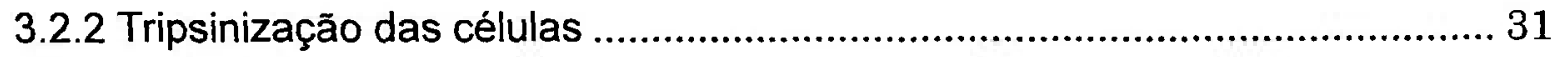

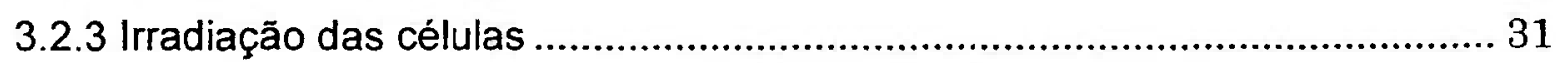

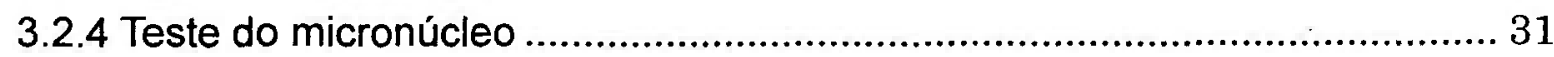

3.2.5 Teste do cometa (Eletroforese em microgel) ............................................ 33

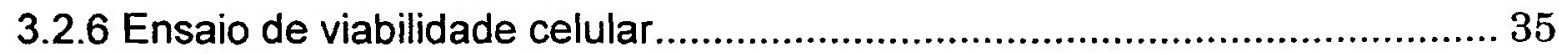

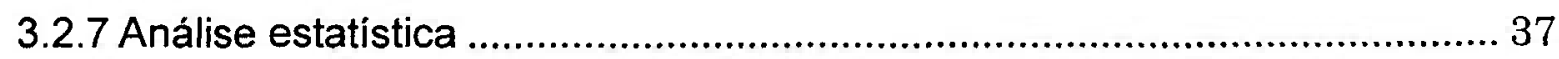

4 RESULTADOS

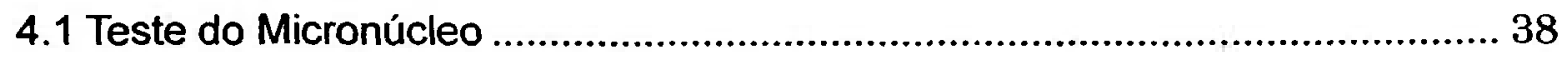




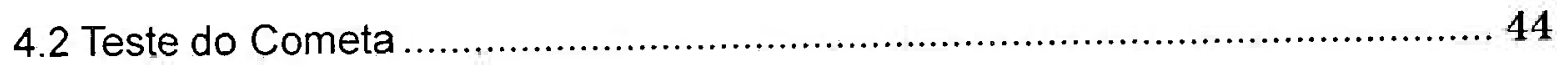

4.3 Teste de Viabilidade Celular.................................................................... 51

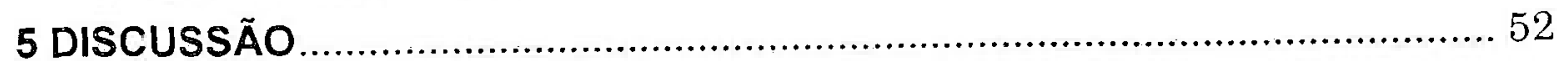

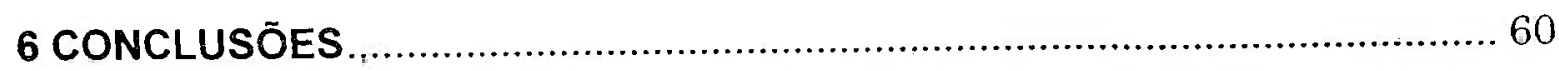

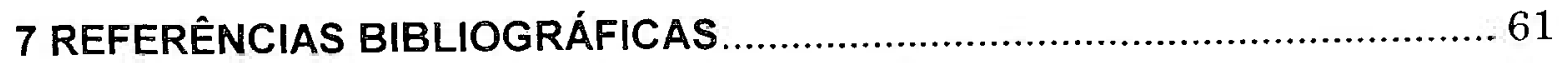




\section{INTRODUÇÃO}

O câncer pode ser definido como um conjunto de diversas doenças que têm em comum o crescimento desordenado de células anormais que invadem tecidos e órgãos, podendo espalhar-se para outras regiões do corpo. Por ser uma doença de alta incidência é considerada um problema de saúde pública no mundo inteiro, inclusive no Brasil. Constitui a segunda causa de morte por doenças no país, atrás somente de problemas cardiovasculares. Segundo o Instituto Nacional de Câncer (INCA/PRO-ONCO), só no ano de 2008 serão 466.730 novos casos, incluindo todas as neoplasias (Tabela 1).

A etiologia do câncer é variada, podendo ser endógena, exógena ou ambas. Por ser uma doença multifatorial pode ser resultante de vários fatores, ambientais, hormonais, hereditários ou inter-relação entre eles.

A maioria dos cânceres humanos pode ser atribuivel aos fatores externos ambientais que são teoricamente evitáveis que agem concomitantemente com a suscetibilidade dos indivíduos. Somente uma fração muito pequena de incidência de câncer é oriunda de fatores hereditários, por exemplo, retinoblastoma, tumor de Wilm, vários tipos de câncer da sindrome LiFraumeni (Perera, 1997). A síndrome da fragilidade cromossômica, como a anemia de Fanconi, ataxia telangectasia e xeroderma pigmentosum, apresenta também um componente hereditário e é uma doença autossômica recessiva, cujos indivíduos acometidos são deficientes em reparo e, portanto, apresentam uma predisposição genética ao desenvolvimento neoplásico quando expostos à ação de mutagênicos específicos (Machado \& Menck, 1997).

Como exemplos de fatores de risco externos podem levar em consideração àqueles relacionados aos hábitos e estilo de vida (tabagismo, consumo de álcool e dieta alimentar), ao ambiente de trabalho (exposições aos agentes químicos e físicos), ao meio ambiente (contaminação da terra, ar, água e alimentos) e à intervenção terapêutica (medicação, radiação) (Venitt, 1994; INCA, 2007). 
TABELA 1 - Estimativa da incidência de câncer para 2008 no Brasil.

\begin{tabular}{|c|c|c|c|}
\hline \multirow[t]{2}{*}{ Localização primária } & \multicolumn{3}{|c|}{ Estimativa de casos novos } \\
\hline & Masculino & Feminino & Total \\
\hline Próstata & 49.530 & - & 49.530 \\
\hline Mama Feminiria & - & 49.400 & 49.400 \\
\hline Traquéia, Brônquio e Pulmão & 17.810 & 9.460 & 27.270 \\
\hline Cólon e Reto & 12.490 & 14.500 & 26.990 \\
\hline Estômago & 14.080 & 7.720 & 21.800 \\
\hline Colo do útero & - & 18.680 & 18.680 \\
\hline Cavidade oral & 10.380 & 3.780 & 14.160 \\
\hline Esôfago & 7.900 & 2.650 & 10.550 \\
\hline Leucemias & 5.220 & 4.320 & 9.540 \\
\hline Pele e Melanoma & 2.950 & 2.970 & 5.920 \\
\hline Outras localizações & 55.610 & 62.270 & 117.880 \\
\hline Subtotal & 175.970 & 175.750 & 351.720 \\
\hline Pele não-melanoma & 55.890 & 59.120 & 115.010 \\
\hline Todas as neoplasias & 231.860 & 234.870 & 466.730 \\
\hline
\end{tabular}

Fonte - INCA, 2008. 


\subsection{Considerações gerais sobre o câncer de mama}

Entre vários tipos de câncer, o de mama tem recebido uma atenção especial nestes últimos anos em virtude da sua alta incidência entre as mulheres, representando cerca de uma em cada três de todas as neoplasias femininas (Jameel et al., 2004). O câncer de mama atualmente é a causa mais comum de morte nas mulheres em quase todos os paises do mundo. No Brasil, o número de novos casos espèrados em 2008 é de 49.400, com um risco estimado de 51 casos a cada 100 mil mulheres (INCA, 2008). Nas mulheres, a doença é freqüentemente diagnosticada entre 40 e 60 anos de idade.

O câncer de mama é considerado de bom prognóstico, se diagnosticado e tratado precocemente. Porém, o diagnóstico realizado em fase avançada da doença pode ser o maior responsável pela manutenção das taxas de mortalidade elevadas (Who, 2002). Assim sendo, várias modalidades de tratamentos têm sido adotadas, dependendo do tamanho do tumor, do comprometimento dos linfonodos e da análise anátomo-patológica. A intervenção cirúrgica e a radioterapia têm sido amplamente utilizadas e os tratamentos sistêmicos como a hormono e quimioterapias são também bastante difundidos. Muitas vezes, uma combinação destes procedimentos é adotada para maximizar beneficios e minimizar os riscos (Schmidberger et al., 2003).

Determinados grupos de mulheres apresentam uma maior probabilidade de desenvolver a neoplasia. Essas mulheres têm em comum certas características denominadas de fatores de risco. Tais fatores propiciam condições favoráveis ao desenvolvimento da doença, mas não obrigatoriamente levarão ao câncer de mama, ou seja, apenas apresentarão uma maior probabilidade de desenvolvê-lo (cerca de $80 \%$ ) quando comparadas com a população feminina em geral (INCA, 2003).

Dentre os fatores de risco endógenos, pode-se citar a influência hormonal como estrogênio e progesterona, cuja exposição mais prolongada sobre a mama (menarca precoce, menopausa tardia, nuliparidade, primeiro parto após 
30 anos relacionado ao maior número de ciclos ovulatórios) pode aumentar o risco de indução neoplásica pelo aumento da proliferação celular em órgão alvo. As repetidas divisões celulares resultam no aumento do número de células-alvo, propiciando dessa maneira o acúmulo de mutações somáticas espontâneas, que em última instância poderá desencadear o desenvolvimento neoplásico (Key, 1995).

Os fatores de risco exógenos podem ser representados pela exposição aos carcinógenos físicos e químicos e a outros componentes relacionados às condições de vida do indivíduo. Entre os agentes externos, a radiação ionizante tem recebido um destaque especial nestas últimas décadas em consonância com a sua maior utilização nas mais diversas áreas da atividade humana.

Estudos epidemiológicos apontam que cerca de $90 \%$ dos casos de câncer de mama são esporádicos, atribuiveis aos eventos somáticos e cerca de $10 \%$ apresentam uma história familial e destes somente $4-5 \%$ são decorrentes de fatores hereditários (Newman et al., 1988; Blasiak et al., 2004).

Aproximadamente $80-90 \%$ dos casos hereditários de câncer de mama e ovário estão associados com mutações germinativas nos genes BRCA1 ou BRCA2 (Nieuwenhuis et al., 2002; Blasiak et al., 2004). Mutações no gene BRCA2 conferem também um risco aumentado de câncer de mama e próstata nos homens (Wang et al., 2001). Porém, a herança de uma mutação germinativa no gene BRCA1, embora associada com uma incidência aumentada de câncer de mama, não é a única responsável para o desenvolvimento de câncer em mulheres predispostas. Alterações adicionais somáticas múltiplas são necessárias para o desenvolvimento de tumores mamários em mulheres com predisposição genética.

O gene BRCA1 ("breast cancer") foi identificado em 1990 no cromossomo 17q21 por um grupo de pesquisadores liderado por Mary-Claire King (Hall et al., 1990) por apresentar uma relação direta com a forma hereditária de câncer de mama. Pertence ao grupo de genes supressores tumorais e faz parte 
do complexo sistema de interação de vários genes que, entre outras funções, impede a proliferação excessiva de células (Miki et al., 1994; Rahman \& Stratton, 1998). Igualmente, o gene BRCA2 foi mapeado em 1994 no cromossomo 13q1213 (Wooster et al., 1994) e clonado em 1996 (Tavtigian et al., 1996). Ambos os genes codificam proteinas nucleares de 1863 e 3418 resíduos de aminoácidos, respectivamente, que se expressam em vários tecidos (mama, ovário, testículos, timo), porém suas funções especificas ainda não estão totalmente elucidadas (Wang et al., 2001; Nieuwenhuis et al., 2002).

Estudos moleculares relativamente recentes têm mostrado que o BRCA1 e BRCA2, conhecidos como genes da suscetibilidade ao câncer de mama, juntamente com outros genes ( 553, p21, ATM, Bax, c-abl), participam no reparo da quebra na fita dupla do DNA (Kotsopoulos et al., 2007), no controle do ciclo celular e na morte apoptótica (Thompson \& Schild, 2002; Jameel et al., 2004; Zhan, 2005).

Apesar das mutações nos genes BRCA1 e BRCA2 serem responsáveis pela maioria dos casos hereditários de câncer de mama e ovário, há controvérsia sobre o papel desempenhado por esses genes nos casos esporádicos de câncer de mama. A análise molecular dos genes tem revelado que, muitos casos de câncer de mama/ovário esporádicos nem sempre são acompanhados de mutações somáticas nos genes BRCA1 e BRCA2 (Futreal et al., 1994; Merajver et al., 1995; Scully et al., 1997; Rahman \& Stratton, 1998). Estas e outras observações levaram a alguns investigadores (Futreal et al., 1994) a lançarem hipótese de que tumores esporádicos e hereditários provavelmente têm diferentes etiologias, sugerindo que o BRCA1 e BRCA2 podem não apresentar um papel crítico na gênese de casos esporádicos de câncer de mama. A ausência de mutações somáticas nesses genes faz supor a influência de outros genes que agem na mesma rota da supressão tumoral ou mesmo em outras rotas bioquimicas, tendo em vista a complexidade do processo neoplásico.

Outro gene que está associado com o risco de indução de câncer de mama é o gene mutado da ataxia telangectasia (ATM), cujo indivíduo afetado 
apresenta uma alta sensibilidade à ação da radiação ionizante (Mamon et al., 2003). O gene ATM se localiza no cromossomo 11q22.3 (Gatti et al., 1993) e foi clonado em 1995 (Savitsky et al., 1995) e desde então descobriu-se que o gene codifica uma proteína kinase de 3056 resíduos de aminoácidos, que faz parte da familia da fosfatidilinositol 3-kinase (PI3-K), apresentando vários substratos dos quais incluem genes p53, HDM2, BRCA1, chk2, c-abl e NBS1, entre outros. Foi identificado que o ATM representa um papel central na regulação da resposta celular ao dano no DNA induzido pela radiação ionizante pelas proteínas fosforiladas numa rede de sinalização celular responsável pelo bloqueio do ciclo celular, ativação da rota do reparo e morte celular (Mamon et al., 2003).

Entre vários genes-alvos do ATM, inclui o supressor tumoral p53, cuja mutação neste gene está envolvida em mais de $70 \%$ de todos os cânceres humanos, incluindo o de mama (Khanna \& Chenevix-Trench, 2004). O gene p53 foi identificado por Levine e colaboradores em 1979, se localiza no cromossomo 17p13.1 e codifica uma proteina de 393 resíduos de aminoácidos (Lee et al., 1997). Quando ativado aciona uma série de genes-alvos que participam no bloqueio do ciclo celular ( $\mathrm{p} 21$, um inibidor de proteina kinase dependente de ciclina), apoptose (Bax) e reparo (Gadd45). Tem um papel fundamental em organismos multicelulares para impedir a instalação do processo tumorigênico e tem sido descrito como o "guardião do genoma", devido ao seu papel na manutenção da estabilidade genômica. A função primordial do p53 em células fisiologicamente normais é a de impedir a proliferação de células com o DNA alterado por meio da interrupção do ciclo celular ("checkpoint") (Figura 1), particularmente na fase $\mathrm{G} 1$, garantindo dessa maneira o tempo suficiente para que ocorra o reparo antes da síntese do DNA. Uma vez que o reparo não é possivel, o p53 aciona o processo apoptótico, impedindo dessa maneira a propagação de células indesejáveis que carregam mutações (Lacroix et al., 2006). O p53 participa também no mecanismo de reparo celular para manutenção da integridade genômica (Bennett, 1999). 


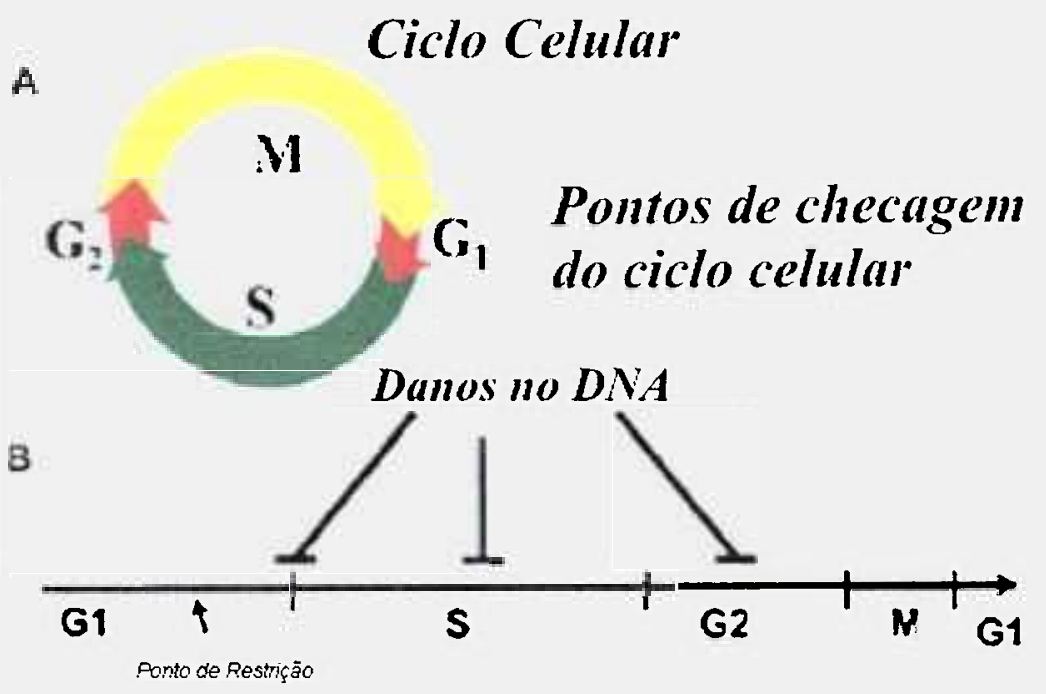

FIGURA 1 - Pontos de checagem ("checkpoint") do DNA. (A) Representação diagramática do ciclo celular: fase $S$, onde o DNA é duplicado e fase $M$, onde o DNA é distribuido de forma equitativa às duas células-filhas. Duas fases, G1 e G2, separam os dois eventos principais. (B) Representação esquemática dos pontos de checagem do DNA. As células interrompem o ciclo em $\mathrm{G} 1$ antes da fase $S$ (ponto de checagem $\mathrm{G} 1 / \mathrm{S}$ ), interrupção temporária da sintese de DNA na fase $S$ (ponto de checagem na fase $S$ ) e interrupção do ciclo em G2 antes da mitose (G2/M) (Khanna \& ChenevixTrench, 2004).

\subsection{Considerações gerais sobre radiação ionizante}

O termo radiação significa propagação de energia em forma de ondas eletromagnéticas ou fótons ou em forma de partículas subatômicas com ou sem carga elétrica. A radiação é dita ionizante quando apresenta energia suficientemente alta, capaz de arrancar elétrons orbitais de átomos ou moléculas do meio por onde se propaga, produzindo pares de ions.

A radiação ionizante é um agente físico que sabidamente induz mutações e câncer. Dados epidemiológicos apontam a radiação ionizante como um agente etiológico estabelecido na incidência de vários tipos de câncer, inclusive o de mama (Tokunaga et al., 1987; Blasiak et al., 2004). A radiação ionizante é considerado um agente carcinogênico completo, pois pode atuar como um iniciador e promotor tumoral da carcinogênese (Kondo, 1988). É possivel, então, que a radiação ionizante atue em várias das múltiplas etapas da carcinogênese. 
Por outro lado, ela é amplamente utilizada em radiodiagnóstico, na medicina nuclear e na radioterapia para o tratamento de tumores. A despeito da reconhecida potencialidade da radiação ionizante em induzir danos, o seu mecanismo de ação no desenvolvimento neoplásico e a resposta das células frente à radiação ionizante ainda não estão totalmente esclarecidos.

Os efeitos biológicos das radiações são conseqüências de eventos primários produzidos em macromoléculas biologicamente importantes das células, particularmente o DNA, considerado o principal alvo da radiação, dado o papel desempenhado por ele no controle de diversas funçōes celulares. $O$ dano pode ocorrer como resultante da interação direta da radiação ionizante com o DNA, fenômeno este conhecido como ação direta da radiação. Em outras situações, a radiação transfere sua energia primariamente à molécula intermediária, como a da água, cuja radiólise leva à formação de produtos altamente reativos, os radicais livres, que são capazes de difundir e de danificar o DNA, caracterizando dessa forma, a ação indireta da radiação. Esse efeito indireto é o responsável pela maioria dos danos produzidos ao DNA, tendo em vista que $80 \%$ de uma célula é composta de água (Hall, 2000).

Os vários tipos de radiação ionizante diferem na eficácia em produzir danos biológicos (IAEA, 2001). Isso porque quando a energia da radiação é absorvida pelo material biológico, as excitações e as ionizações não se distribuem ao acaso, mas tendem a ser localizadas ao longo do percurso, num padrão que depende do tipo de radiação envolvido. Conseqüentemente, a distribuição espacial de eventos ionizantes produzidos pelos diferentes tipos de radiação vai variar grandemente.

Dessa forma, os efeitos biológicos estão intimamente relacionados com o conceito de transferência linear de energia ("Linear Energy Transfer" ou LET), um parâmetro que define a quantidade de energia média depositada na matéria por unidade de distância percorrida $(\mathrm{keV} / \mu \mathrm{m})$. O valor do LET varia com a velocidade, massa e carga da radiação ionizante (Hall, 2000). De modo geral, as radiaçōes de alto LET, como as particulas $\alpha$ e nêutrons são mais eficazes na produção de danos biológicos que as radiaçōes de baixo LET, como os raios $X$, 
radiação y e partículas $\beta$.

É largamente conhecido que a exposição de células à radiação ionizante resulta em amplo espectro de lesões no DNA, incluindo danos de base, quebras nas fitas simples e duplas, vários tipos de ligações cruzadas entre DNADNA e DNA-proteinas, seja pela ionização direta como por meio de espécies reativas de oxigênio, mediados pelos radicais livres provenientes da radiólise da água (Hall, 2000). A amplitude do dano vai depender, entre outros fatores, essencialmente do tipo de radiação, da dose aplicada e do tipo celular.

Um dos principais danos primários induzidos pela radiação ionizante é a quebra na fita dupla do DNA, envolvendo ambas as fitas, aparentemente no mesmo sítio (Hill, 1999). É considerado o dano mais importante por ser mais difícil de ser reparado e por estar envolvido em vários efeitos de grande significado biológico, como letalidade celular, mutação, malformação e câncer (Jackson, 2002; Sankaranarayanan, 2006). Segundo uma revisão de Schmidberger et al. (2003), uma dose de 1 Gy causa em média, uma quebra na fita dupla do DNA por cromossomo.

No entanto, as lesões ocorridas na estrutura do DNA são prontamente reparadas pelas células por meio da ação de várias enzimas de reparo, preservando dessa maneira, a estabilidade genômica. Danos não reparados ou reparados erroneamente apresentam, portanto, um potencial mutagênico e carcinogênico.

\subsection{Considerações gerais sobre reparo celular}

Sabe-se que a sobrevivência do indivíduo depende da estabilidade do seu genoma. Essa estabilidade resulta não só de um eficiente mecanismo de replicação do DNA, mas também de mecanismos que reparem os danos que ocorrem continuamente ao DNA.

Entende-se por reparo a capacidade da célula em corrigir as alterações induzidas no material genético por agentes mutagênicos. Muitos danos induzidos no DNA podem ser reparados porque a informação genética é preservada em 
ambas as fitas da dupla hélice, de tal forma que a informação alterada ou perdida em uma fita pode ser recuperada a partir da fita complementar. Quebras nas duas fitas de uma mesma molécula de DNA ocorrem nas células em diversas circunstâncias e constituem uma das principais ameaças à integridade do genoma.

Várias vias de reparo são acionadas pelas células, dependendo do tipo de lesão formada no DNA por um agente mutagênico específico. Danos de base e quebras nas fitas simples do DNA induzidos pela radiação ionizante, agentes oxidantes e alquilantes são reparados pela ação de enzimas do reparo por excisão de base ("Base Excision Repair" ou BER). Danos que envolvem mudanças na estrutura da dupla hélice do DNA como os dímeros de pirimidinas induzidos pela radiação UV e bases contendo adutos químicos podem ser reparados por excisão de nucleotideos ("Nucleotide Excision Repair" ou NER) (Hoeijmakers, 2001; Khanna \& Jackson, 2001; Svejstrup, 2002). Já as quebras na fita dupla do DNA induzidas pela radiação ionizante e também por alguns agentes antitumorais são reparadas por recombinação homóloga ("Homologous Recombination" ou HR) ou por ligação das extremidades não homólogas (Nonhomologous End-Joining" ou NHEJ) (Xia et al., 2001; Sankaranarayanan, 2006).

\subsubsection{Reparo por ligação das extremidades não-homólogas (NHEJ)}

É a via mais utilizada pelas células de mamíferos (Fig. 2A). Nesse mecanismo, as duas extremidades de uma molécula de DNA, apesar de perderem alguns nucleotídeos são justapostas para recombinar. Um complexo enzimático realiza o processo de ligação entre as duas extremidades, porém a seqüência original de DNA pode ser alterada, podendo ocasionar pequenas deleções durante o processo (Alberts, 2002; Zaha, 2003; Sankaranarayanan, 2006).

Embora várias proteínas participem do reconhecimento e na resposta à 
quebra na fita dupla do DNA, seis dessas proteinas estão diretamente envolvidas no reparo. Três delas são componentes da proteina kinase dependente do DNA (DNA-PK) que inclui Ku70 e Ku80 ou Ku86 que juntos formam um complexo que se liga na extremidade do DNA e a subunidade catalítica DNA-PKcs. Outras três proteínas, a ligase IV do DNA e XRCC4 funcionam como um complexo para ligar as extremidades do DNA e Artemis que em combinação com DNA-PKcs age como uma endonuclease.

Em mamíferos, defeitos nas subunidades Ku ou na DNA-PKcs resultam numa alta sensibilidade à radiação, o que sugere que todo o complexo participa deste processo (Taylor \& Lehmann, 1998; Xia et al., 2001; Sankaranarayanan, 2006). A via de reparo por NHEJ requer pouco ou nenhuma homologia e, portanto, sujeito a erro ("error-prone").

\subsubsection{Reparo por recombinação homóloga (HR)}

Um dos mecanismos reparadores de quebras da fita dupla é a união de extremidades homólogas (Fig. 2B). Na genética clássica, o termo recombinação homóloga é usado para descrever o processo através do qual existe uma troca reciproca de material genético entre os cromossomos homólogos em organismos sexuados (Sankaranarayanan, 2006). Esta via de reparo requer homologia extensiva para restaurar a molécula do DNA, onde uma segunda hélice do DNA não danificada com seqüência similar de base (cromossomo homólogo) é usada como um molde para o reparo e então o processo é efetuado com maior fidelidade e é livre de erro ("error-free"). Esta via de reparo parece ser a única em bactérias, principal rota em leveduras, porém tem um papel relativamente pequeno em células de mamíferos (Taylor \& Lehmann, 1998). 


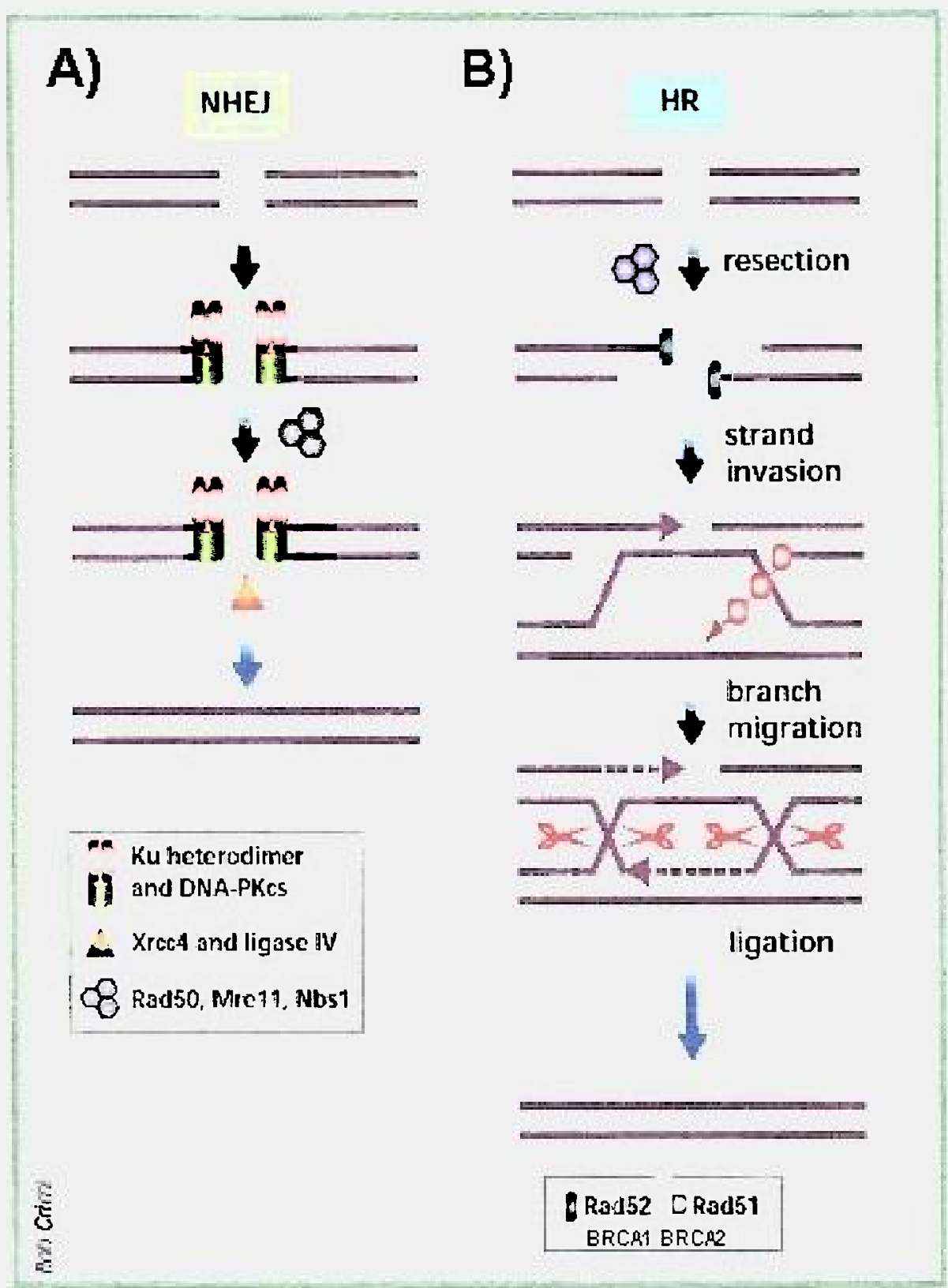

FIGURA 2 - Representação esquemática dos mecanismos evolvidos no reparo da quebra na fita dupla do DNA. Apenas alguns dos genes / produtos protéicos estão indicados. A) Via de reparo por ligação de extremidades não homólogas; B) via de reparo por recombinação homóloga (Khanna \& Jackson, 2001).

\subsection{Considerações gerais sobre técnicas citogenéticas e bioquímicas}

Uma série de metodologias tem sido desenvolvidas e aperfeiçoadas para detectar e quantificar danos induzidos ao DNA pela radiação ionizante em células de mamiferos. Entre elas as técnicas citogenéticas (aberrações 
cromossômicas, troca entre cromátides-irmãs, micronúcleo, hibridização in situ fluorescente - FISH) e bioquímicas (gradientes alcalinos de sacarose, eluição alcalina e neutra, eletroforese alcalina em gel, sedimentação de nucleóide e medidas viscoelásticas de DNA), são amplamente utilizadas em vários sistemas biológicos.

Entre as técnicas citogenéticas, o teste do micronúcleo (MN) foi proposto por ser relativamente simples, sensivel e por ser um bom indicador biológico de danos genéticos induzidos por radiação ionizante ou por agentes quimicos tanto in vivo como in vitro. Essa técnica tem sido muito utilizada por apresentar várias vantagens se comparada à análise convencional de aberração cromossômica, tais como: facilidade na identificação do dano, rapidez no tempo de análise e simplicidade da técnica.

Os micronúcleos representam mutações em nivel cromossômico que resultam da falha no reparo da quebra na fita dupla do DNA. Este tipo de lesão é a principal contribuinte da letalidade celular e da mutação produzida pelos agentes que danificam o DNA (Thompson \& Schild, 2002).

A técnica do micronúcleo foi desenvolvida inicialmente por Schmid (1975), mas apresentava a desvantagem de não discriminar as células que já haviam se dividido daquelas que não se dividiram, o que tornava a contagem do MN pouco precisa. Isto pode ser explicado pelo fato de que, os $M N$ só se manifestam em células que tenham completado uma divisão nuclear, portanto, se a freqüência de $\mathrm{MN}$ é utilizada como um indicador de dano cromossômico, a contagem de $\mathrm{MN}$ deve ser limitada somente àquelas células que tenham completado uma única divisão nuclear após a exposição ao mutagênico.

Para contornar este problema, Fenech \& Morley (1986), aperfeiçoaram - método utilizando a citocalasina-B, também conhecido como método do bloqueio citocinético ("cytokinesis block method"). A citocalasina B é uma substância isolada do fungo Helminthosporum dematoideum, e é um inibidor de 
polimerização de actina, componente do microfilamento responsável pela citocinese, portanto, a citocalasina-B impede a divisão do citoplasma, mas não a divisão do núcleo.

A importância desse teste está no seu papel indicativo; uma alta freqüência de $\mathrm{MN}$ pode estar correlacionada com o aumento de dano ao DNA, o que implica em um maior risco de desenvolver câncer ou doenças genéticas.

Dentre os métodos bioquímicos, o teste do cometa ("single-cell gel electrophoresis") também chamado de eletroforese de microgel, foi primeiramente descrito por Östling \& Johanson (1984), utilizando condições neutras para lise e eletroforese das células, o que permitia somente a avaliação de quebras nas fitas duplas.

Em 1988, Singh et al. descreveram uma técnica que utiliza a versão alcalina do teste, que possibilita a detecção de quebras ocorridas tanto nas fitas simples como duplas e também sítios álcali-lábeis. Assim, a condição alcalina é considerada mais sensivel que a neutra na detecção de lesões primárias radioinduzidas.

O teste do cometa é amplamente empregado por apresentar uma série de vantagens como avaliação de dano em células isoladas, quantidade pequena de amostras da ordem de microlitros $(\mu l)$, utilização de qualquer tipo celular proliferativo ou não, avaliação da capacidade de reparo, além de apresentar uma boa sensibilidade para detecção de danos ocorridos no DNA (Speit \& Hartmann, 1999).

Esse teste parte do principio de que o DNA nuclear de mamíferos está organizado em unidades compactas, ligadas à membrana do núcleo ou à matriz nuclear. Estima-se que moléculas de DNA de células humanas $(5-10 \mathrm{~cm}$ de comprimento para cada cromossomo na intérfase) estão condensadas $10^{5}$ vezes para serem empacotadas dentro de um núcleo de 5-10 $\mu \mathrm{m}$ de diâmetro (Whitaker et al., 1991; Hancock, 2007).

Quebras nas fitas do DNA ocasionariam efeitos drásticos na estrutura 
da cromatina, causando um relaxamento. O filamento do DNA danificado se apresentaria menos compacto e migraria do núcleo em direção ao ânodo quando submetido a um campo elétrico, adquirindo a aparência de um cometa, dando origem ao nome da técnica (teste do cometa) (Östling \& Johanson, 1987).

Esse ensaio tem sido utilizado em várias áreas de estudo, por exemplo, em genética toxicológica, monitoramento ambiental, biomonitoração humana e estudos envolvendo dano ao DNA e capacidade de reparo.

Para a avaliação de viabilidade celular têm sido adotados ensaios utilizando corantes como trypan blue, acredine orange e brometo de etídio, que se baseiam na permeabilidade da membrana e nas características morfológicas das células. A citometria de fluxo também é amplamente empregada. O método colorimétrico utilizando MTS/PMS (tetrazolium 3-(4,5-dimetiltiazol-2-yl)-5-(3carboxi-metoxifenil) -2- (4-sulfofenil)-2H-tetrazolium / metossulfeto de fenazina) descrito por Cory et al. (1988) se baseia na capacidade das células vivas em reduzir o MTS, na presença de um acoplador de elétrons (PMS), em um produto solúvel (formazan) em meio de cultura, graças às enzimas desidrogenases mitocondriais. A quantidade de produto formado é diretamente proporcional ao número de células viáveis na cultura.

Este teste permite avaliar a taxa de morte celular ocasionada por diferentes doses de radiação ionizante, com a principal vantagem de ser relativamente rápido e eficiente na obtenção de dados permitindo a análise de várias amostras ao mesmo tempo (Cory et al., 1991).

\subsection{Considerações gerais sobre suscetibilidade de pacientes com câncer de mama}

Vários estudos têm mostrado que níveis altos de dano ao DNA e deficiência no reparo celular representam principais fatores associados ao risco aumentado de indução de câncer.

Com base nessas observações, muitos estudos foram conduzidos na tentativa de averiguar a suscetibilidade de pacientes com câncer de mama frente 
à ação de agentes genotóxicos. Vários autores verificaram uma sensibilidade aumentada e uma diminuição na capacidade de reparo de linfócitos periféricos de paciente com câncer de mama à ação de raios $X$ e gama (Helzlsouer et al., 1995; Scott et al., 1995; Nascimento et al., 2001; Smith et al., 2003) e luz UV (Parshad et al., 1996), quando comparadas com os dos individuos sadios. Do mesmo modo, outros autores (Jaloszynski et al., 1997; Trenz et al., 2003; Blasiak et al., 2004) encontraram resultados similares quando analisaram efeitos de substâncias quimioterápicas como doxorrubicina, bleomicina, cisplatina e ciclofosfamida em linfócitos de pacientes com câncer de mama.

A despeito dessas considerações, há, no entanto, poucas informaçōes no que diz respeito à resposta de linhagens originárias de câncer de mama, isto é, em células-alvo, frente à ação de agentes genotóxicos como a radiação ionizante. Pode-se, no entanto, mencionar o trabalho de Mamon et al. (2003) que analisaram o efeito de raios $\mathrm{X}$ em linhagens fibroblásticas originárias de tumor de mama com mutações no BRCA1 e p53 (HCC1937) e no gene ATM (AGO4405, GMO2052 e AGO3057). Verificaram uma maior sensibilidade à radiação ionizante, uma deficiência no reparo do dano potencialmente letal e um aumento pronunciado na freqüência de aberrações cromossômicas. 


\section{OBJETIVO}

O presente trabalho foi proposto para analisar citologicamente, efeitos da radiação gama de ${ }^{60} \mathrm{Co}$ em linhagens tumorais (T-47D e MCF-7) e não tumorais (MCF-10), originárias de mama humana. Para tanto, foram utilizados como principais parâmetros de análise, dano induzido ao DNA, capacidade de reparo e morte celular, por meio das técnicas do micronúcleo, do cometa e do teste de viabilidade celular. A escolha desses parâmetros se justifica pelo seu significado biológico, além de serem prontamente observáveis e mensuráveis em células irradiadas. 


\section{MATERIAIS E MÉTODOS}

\subsection{Materiais}

\subsubsection{Linhagem Celular}

Linhagem MCF-7 (células tumorais de mama humana), obtida de American Type Culture Colletion, (Rockville, MD)

> Linhagem MCF-10 (células não tumorais de fibrose cística de mama humana), gentilmente doada pela Dra Maria Helena Bellini Maruno do Instituto de Pesquisas Energéticas e Nucleares (IPEN/CNEN-SP)

> Linhagem T-47D (células tumorais de mama humana), obtida de American Type Culture Colletion, (Rockville, MD)

\subsubsection{Material utilizado na cultura celular}

> Ácido etilenodiaminotetracético (EDTA), LABSYNTH (São Paulo, SP, Brasil)

$>$ Dimetilsulfóxido (DMSO), MERK (São Paulo, SP, Brasil)

> Fator de crescimento epitelial (EGF), INVITROGEM (Carisbad, CA, EUA)

$>$ Gentamicina, SHERING-PLOUGT (Rio de Janeiro, Brasil)

$>$ Hidrocortisona, CALBICHEM - NOVABIOCHEM CORPORATION (La Jolla, CA, EUA)

$>$ Insulina, SIGMA (St. Louis, MO, EUA)

$>$ Meio Mínimo Essencial Eagle's Dulbecco's (D-MEM), GIBCO-BRL (Gaithersburg, MD, EUA)

> Meio F12K, GIBCO-BRL (Gaithersburg, MD, EUA)

> Meio RPMI 1640, GIBCO-BRL (Gaithersburg, MD, EUA)

$>$ Penicilina, estreptomicina, GIBCO-BRL (Gaithersburg, MD, EUA)

$>$ Soro fetal bovino (SFB), GIBCO-BRL (Gaithersburg, MD, EUA)

$>$ Soro de cavalo, GIBCO-BRL (Gaithersburg, MD, EUA)

$>$ Tripsina, GIBCO-BRL (Gaithersburg, MD, EUA)

$>$ Toxina Colérica, SIGMA (St. Louis, MO, EUA)] 


\subsubsection{Material Plástico}

> Garrafas de $75 \mathrm{~cm}^{2}$, CORNING COSTAR CORP. (NY, EUA)

> Pipetas de 2, 5, 10 e $25 \mathrm{~mL}$, CORNING COSTAR CORP. (NY, EUA)

$>$ Placas de 96 poços, CORNING COSTAR CORP. (NY, EUA)

$>$ Sistema de Filtração de $500 \mathrm{~mL}, 0,22 \mu \mathrm{m}$, CORNING COSTAR CORP. (NY, EUA)

> Tubos criogênicos de $2 \mathrm{~mL}$, CORNING COSTAR CORP. (NY, EUA)

$>$ Tubos para centrifuga de 15 e $50 \mathrm{~mL}$, CORNING COSTAR CORP. (NY, EUA)

$>$ Tubos cônicos com tampa de 1,5 mL, Eppendorf (Hamburgo, Alemanha).

\subsubsection{Reagentes utilizados no teste do micronúcleo}

$>$ Citocalasina - B (St. Louis, MO, EUA).

\subsubsection{Fixador}

i Ácido acético, MERK (São Paulo, SP, Brasil)

$>$ Formaldeido, MERK (São Paulo, SP, Brasil)

$>$ Metanol, MERK (São Paulo, SP, Brasil)

\subsubsection{Tampão Sorensen}

$>$ Fosfato monobásico de potássio $\left(\mathrm{KH}_{2} \mathrm{PO}_{4}\right)$, LABSYNTH (São Paulo, SP, Brasil)

> Fosfato monohidratado dibásico de sódio $\left(\mathrm{Na}_{2} \mathrm{HPO}_{4} \mathrm{H}_{2} \mathrm{O}\right)$, LABSYNTH (São Paulo, SP, Brasil)

\subsubsection{Corante}

> Giemsa, BERSE (São Paulo, SP, Brasil)

$>$ Glicerina, MERCK (São Paulo, SP, Brasil)

$>$ Metanol, MERCK (São Paulo, SP, Brasil) 
3.1.5 Reagentes utilizados no teste do cometa

3.1.5.1 Tampão de eletroforese

> Ácido etilenodiaminotetracético (EDTA), LABSYNTH (São Paulo, SP, Brasil)

$>$ Hidróxido de Sódio ( $\mathrm{NaOH}$ ), MERCK (São Paulo, SP, Brasil)

\subsubsection{Tampão neutralizador}

$>$ TRIS, MERCK (São Paulo, SP, Brasil)

\subsubsection{Solução de lise-mãe}

> Cloreto de Sódio (NaCl), LABSYNTH (São Paulo, SP, Brasil)

$>$ Ácido etilenodiaminotetracético (EDTA), LABSYNTH (São Paulo, SP, Brasil)

$>$ TRIS, MERCK (São Paulo, SP, Brasil)

$>$ Hidróxido de Sódio ( $\mathrm{NaOH}$ ), MERCK (São Paulo, SP, Brasil)

> Sarcosinato de Sódio, FLUKA CHEMIE (Buchs, Suiça)

\subsubsection{Solução de lise-uso}

> TRITON X-100, Fundação SARDI (São Paulo, SP, Brasil).

$>$ Dimetilsulfóxido (DMSO), MERCK (São Paulo, SP, Brasil).

\subsubsection{Agarose "Low Melting"}

$>$ Agarose "Low Melting", LIFE TECHNOLOGIES, INC. (Gainthersburg, USA).

\subsubsection{Agarose "Normal Melting"}

$>$ Agarose normal, SIGMA (St. Louis, MO, EUA)

3.1.6 Reagentes utilizados no ensaio de viabilidade celular

$>$ MTS, PROMEGA CORPORATION (Madison, WI,E UA)

$>$ PMS, SIGMA (St. Louis, MO, EUA) 


\subsubsection{Equipamentos utilizados}

> Autoclave de mesa, série 2100, KAVOKLAVE (São Paulo, SP, Brasil)

$>$ Banho-maria, modelo 100, FANEN (São Paulo, SP, Brasil)

>Centrífuga de bancada, modelo LS 3 plus , CELM (São Paulo, SP, Brasil)

> Cuba Horizontal de Eletroforese, PERMATRON (Illinois, EUA)

$>$ Estufa para cultura de células, 3159, FORMA SCIENTIFIC (Marietta, OH, EUA)

$>$ Fluxo laminar vertical classe II A/B3, 1140, FORMA SCIENTIFIC (Marietta, $\mathrm{OH}, \mathrm{EUA})$

Fonte para eletroforese electrophoresis power supply EPS-300, (Piscataway, EUA)

> Microscópio óptico, CARL ZEISS (Oberkochen, Alemanha)

> Microscópio invertido, ID 03, CARL ZEISS (Oberkochen, Alemanha)

$>$ Purificador de água, Milli-Q-plus, MILLIPORE (Bedford, MA, EUA)

$>$ Sistema de estocagem de criotubos em nitrogênio líquido, Locator Junior, THERMOLYNE (Dubuque, IA, EUA)

$>$ Sistema de estocagem de criotubos, $1^{\circ} \mathrm{C}$ Freezing container, NALGENE COMPANY (Rochester, NY, EUA)

\subsubsection{Fonte de irradiação}

$>$ Fonte panorâmica de ${ }^{60} \mathrm{Co}$, Yoshizawa Kiko Company LTD (Japão) disponivel no Centro de Tecnologia das Radiações (CTR) do Instituto de Pesquisas Energéticas Nucleares (IPEN - CNEN/SP). 


\subsection{Métodos}

\subsubsection{Cultura celular}

No presente trabalho foram utilizadas linhagens celulares tumorais, $T$ 47D (carcinoma ductal) e MCF-7 (adenocarcinoma) e não tumorais, MCF-10, de mama humana, de origem epitelial. As células T-47D e MCF-7 (células isoladas de efusão pleural de pacientes com carcinoma invasivo de mama) foram cultivadas em meio RPMI 1640, suplementado com $10 \%$ de soro fetal bovino e $1 \%$ de penicilina e estreptomicina.

As células MCF-10 (células isoladas de glândula mamária de paciente com fibrose cistica) foram cultivadas no meio composto de DMEM e F12 (1:1), contendo fator de crescimento epidermal $(20 \mathrm{ng} / \mathrm{ml})$, toxina colérica $(100 \mathrm{ng} / \mathrm{ml})$, insulina $(0,01 \mathrm{mg} / \mathrm{ml})$, hidrocortisona $(500 \mathrm{ng} / \mathrm{ml})$ e $5 \%$ de soro de cavalo, acrescidos de $1 \%$ de penicilina e estreptomicina. Todas as linhagens celulares foram mantidas a $37^{\circ} \mathrm{C}$ com $5 \%$ de $\mathrm{CO}_{2}$ em atmosfera úmida (Figura 3 ).

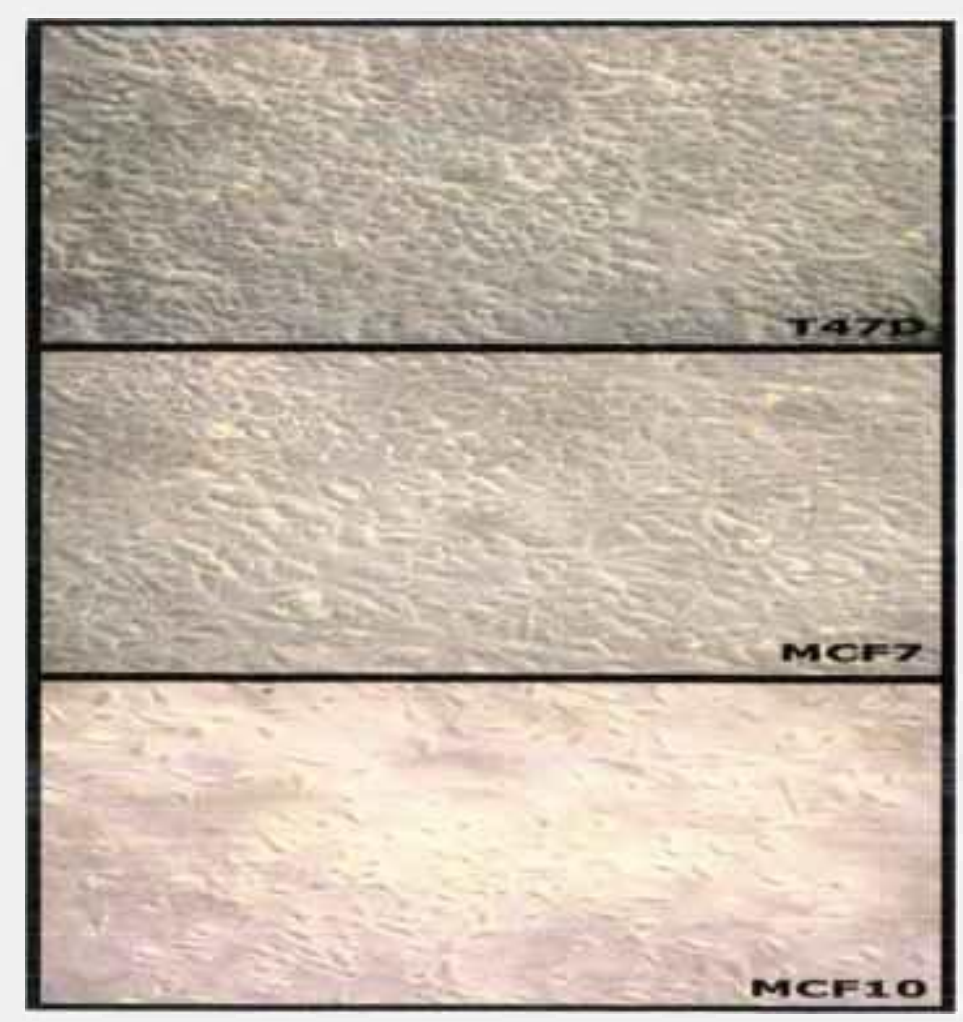

FIGURA 3 - Fotomicrografias de células estudadas em seus respectivos meios de cultura. Aumento de 200x. 


\subsubsection{Tripsinização das células}

Essa etapa é necessária para a manutenção e suspensão das células para os ensaios, uma vez que elas se aderem às placas. Para tanto, as células em confluência mantidas em placas de Petri $(6 \mathrm{~cm}$ de diâmetro) ou em frascos de $25 \mathrm{~cm}^{2}$, foram lavadas com PBS e a seguir, foi adicionado $\sim 0,5 \mathrm{~mL}$ de tripsina $(0,25 \%$ sem EDTA para as linhagens T-47D e MCF-7 e tripsina $0,25 \%$ com $0,1 \%$ de EDTA em PBS para a linhagem MCF-10) (Starcevic et al., 2001). Após incubação com tripsina, as células foram ressuspensas em meio fresco, transferidas para tubos Falcon de $15 \mathrm{~mL}$ com fundo cônico e centrifugadas a 1500 rpm por 5 minutos. Após troca de meio, as células foram homogeneizadas e semeadas em placas.

\subsubsection{Irradiação das células}

As células foram irradiadas na fase exponencial de crescimento em uma fonte panorâmica de ${ }^{60} \mathrm{Co}$ (Yoshizawa Kiko, Japão). Para tanto, as células mantidas em seus respectivos meios de cultura foram acondicionadas em tubos Eppendorf siliconizados. Foram irradiadas nas concentrações de $5 \times 10^{5}$ a $1 \times 10^{6} / \mathrm{mL}$ com doses de 0,$5 ; 1 ; 2 ; 4$ e 5 Gy $(0,72$ Gy/min) para testes do micronúcleo e cometa e $5 ; 10 ; 20$ e $30 \mathrm{~Gy}(1,5 \mathrm{~Gy} / \mathrm{min})$ para teste de viabilidade celular, a temperatura ambiente. Após a exposição, as células foram mantidas nos seus respectivos meios de cultivo a $37^{\circ} \mathrm{C}$ com $5 \%$ de $\mathrm{CO}_{2}$. Uma amostra não irradiada foi utilizada como controle para cada uma das linhagens celulares.

\subsubsection{Teste do micronúcleo}

Para a avaliação citogenética de danos radioinduzidos foi utilizado o teste do micronúcleo ( $\mathrm{MN}$ ) pelo método de bloqueio citocinético utilizando citocalasina-B (Fenech \& Morley, 1986) com algumas alterações (Murakami et al., 2004). O método consiste, basicamente, em cultivar células irradiadas ou não em respectivo meio e a citocalasina-B é adicionada à cultura logo após as irradiações na concentração final de $2 \mu \mathrm{g} / \mathrm{mL}$ para indução de células binucleadas (Figura 4). 
A citocalasina-B impede a citocinese (divisão do citoplasma) sem afetar a cariocinese (divisão do núcleo) e assim dependendo do número de divisões pelas quais as células passam, essas podem apresentar dois ou mais núcleos.

Após 72 horas de incubação, as células foram tripsinizadas, centrifugadas, ressuspensas em solução isotônica de $\mathrm{NaCl}(0,85 \%)$, fixadas com metanol e ácido acético (3:1), gotejadas com pipeta Pasteur sobre lâminas histológicas sob vapor a $65^{\circ} \mathrm{C}$ e secas a temperatura ambiente por uma noite. As lâminas foram coradas com Giemsa $5 \%$ em tampão Sorensen ( $\mathrm{pH} \mathrm{6,8)}$ por 15 minutos, enxaguadas duas vezes em água destilada e secas novamente à temperatura ambiente por uma noite.

Para identificação de micronúcleos foram adotados os critérios estabelecidos pela IAEA (2001): só foram quantificados micronúcleos em células binucleadas com citoplasma preservado, com coloração igual à do núcleo principal e que não estavam em contato com o núcleo principal. Células com mais de 5 micronúcleos não foram consideradas. Dois parâmetros foram levados em consideração: incidência de células afetadas (\% de células binucleadas com MN) e grau de dano intracelular (número de MN/célula).

Foram analisadas no mínimo 500 células binucleadas (CB) por dose de radiação, onde também foram quantificadas células mononucleadas (CM) e multinucleadas $(\mathrm{CMu})$ com ou sem micronúcleos para o cálculo do indice de proliferação (IP) que avalia a cinética de divisão celular (Surralles et al., 1992) segundo a fórmula:

$\mathrm{IP}=\left(\mathrm{n}^{\circ}\right.$ de $\mathrm{CM}+2 \times \mathrm{n}^{\circ}$ de $\mathrm{CB}+3 \times \mathrm{n}^{\circ}$ de $\left.\mathrm{CMu}\right) /$ total de células

Foram realizados no mínimo três ensaios independentes para cada linhagem celular. Todas as lâminas foram identificadas $e$ analisadas no microscópio óptico (Carl Zeiss) no aumento de 400 vezes. 


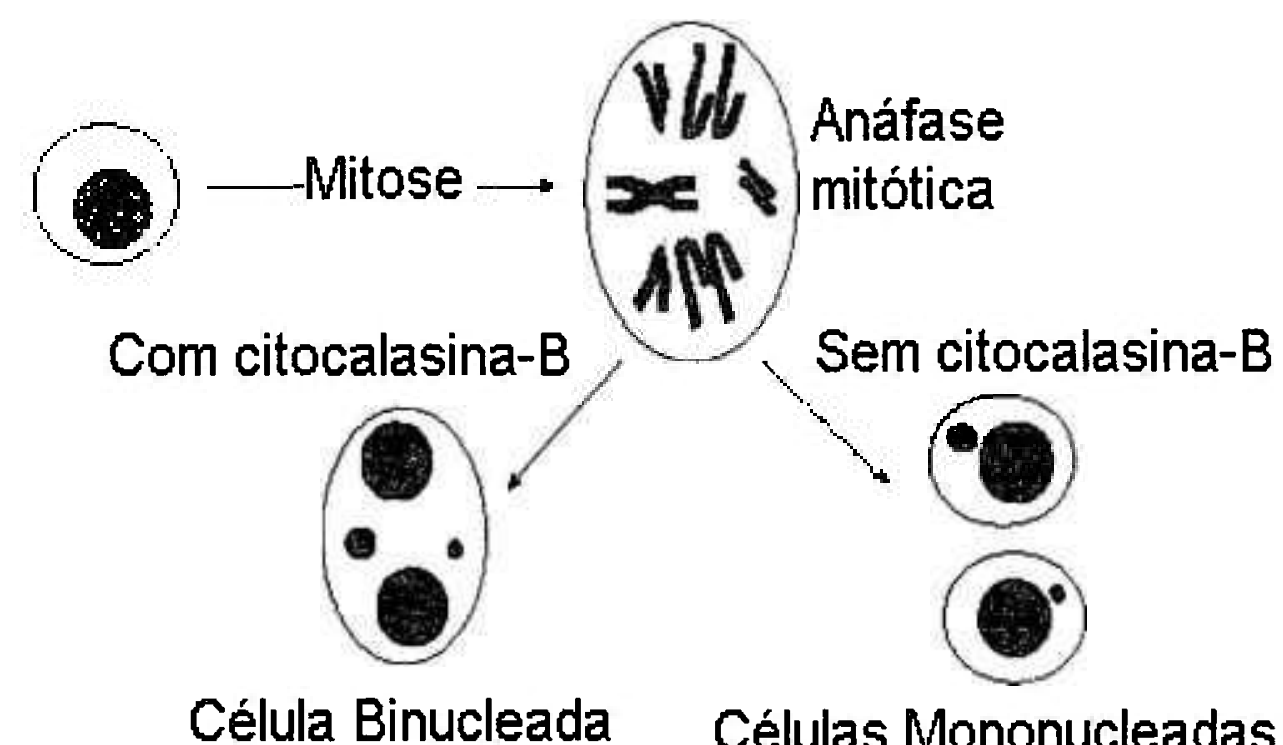

FIGURA 4 - Bloqueio provocado pelo citocalasina-B e a conseqüente obtenção de células binucleadas (Fenech \& Morley, 1985).

\subsubsection{Teste do cometa (Eletroforese em microgel)}

Foi adotada a versão alcalina do teste do cometa descrito por Singh et al. (1988), Nascimento et al. (2001) e Oliveira et al. (2001).

Para avaliar o dano inicial logo após as irradiações $(0 \mathrm{~h})$, as células foram conservadas em uma cuba de gelo para impedir o reparo do dano radioinduzido. Para avaliação da capacidade de reparo 30 minutos, 1 e 3 horas após as irradiações, as células foram mantidas em seus respectivos meios de cultura a $37^{\circ} \mathrm{C}$ com $5 \%$ de $\mathrm{CO}_{2}$.

Para cada dose de radiação, as lâminas (em triplicata) foram previamente embebidas em agarose com ponto de fusão normal $(1,5 \%)$ (dissolvida em tampão PBS livre de $\mathrm{Ca}$ e $\mathrm{Mg}$, a $65^{\circ} \mathrm{C}$ ) e secas a temperatura ambiente. Aliquotas de $10 \mu$ de suspensão celular contendo cerca de $5 \times 10^{3}$ a 1 $\times 10^{4}$ células dissolvidas em $90 \mu \mathrm{l}$ de agarose com baixo ponto de fusão $(0,5 \%)$ (em tampão PBS livre de $\mathrm{Ca}$ e $\mathrm{Mg}$, a $37^{\circ} \mathrm{C}$ ) foram colocadas sobre a lâmina histológica. Após a solidificação das camadas de agarose $\left(5\right.$ minutos a $\left.4^{\circ} \mathrm{C}\right)$, as 
células foram tratadas com uma solução de lise composta de detergentes e sais em alta concentração $(2,5 \mathrm{M}$ de $\mathrm{NaCl}, 100 \mathrm{mM}$ de EDTA, $10 \mathrm{mM}$ de Tris, $1 \%$ de sarcosinato de sódio, $1 \%$ de triton $\mathrm{X}$ e $10 \%$ de $\mathrm{DMSO}$ ) por no mínimo 2 horas a $4^{\circ} \mathrm{C}$ para remoção das proteínas. Em seguida, as lâminas foram colocadas lado a lado em uma cuba de eletroforese horizontal (17x 20cm) (PERMATRON) contendo um tampão alcalino de eletroforese (1 mM de EDTA e $300 \mathrm{mM}$ de $\mathrm{NaOH}, \mathrm{pH}>12$ ) por 30 minutos para que ocorra a expressão de quebras nas fitas e sítios álcali-lábeis do DNA. A seguir, as células foram submetidas à corrida eletroforética (20V e $300 \mathrm{~mA}$ ) (Pharmacia) por 30 minutos a $4^{\circ} \mathrm{C}$.

As lâminas foram neutralizadas 3 vezes por 5 minutos com $0,4 \mathrm{M}$ de tampão TRIS $(\mathrm{pH} 7,5)$ e imersas em etanol $100 \%$ por 10 minutos para armazenamento e posterior análise. A coloração foi feita com $50 \mu \mathrm{l}$ de brometo de etídio (SIGMA) $(20 \mu \mathrm{g} / \mathrm{mL})$ para análise de imagem no microscópio de fluorescência (Carl Zeiss) no aumento de 200 vezes, equipado com filtro de excitação $(515-560 \mathrm{~nm})$ e filtro de barreira $(590 \mathrm{~nm})$. Aproximadamente, 50 cometas escolhidos aleatoriamente foram analisados para cada dose de radiação.

\subsubsection{Critérios de análise}

Os cometas foram analisados pela classificação visual de acordo com o critério estabelecido por Jaloszynski et al. (1997) e por Mozdarami et al. (2007). Os cometas foram classificados em 5 categorias (0 - IV) de acordo com a intensidade do dano ao DNA. Cometas com uma cabeça brilhante e sem cauda foram classificados como classe 0 (sem migração do DNA) e cometas com uma pequena cabeça e cauda longa e difusa, como classe IV (extremamente danificados). Cometas com aspectos intermediários foram classificados como classes I, II ou III (Figura 5).

A estimativa quantitativa do dano ao DNA foi determinada pela fórmula descrita por Jaloszynski et al. (1997), que variou de 0 a 400 unidades arbitrárias:

$$
D D=(n 1+2 n 2+3 n 3+4 n 4) /(\Sigma / 100)
$$


Onde DD = dano ao DNA em unidade arbitrária, $\mathrm{n} 1$ - n4 = número de cometas das classes I - IV, $\Sigma=$ número total de cometas analisados, incluindo os de classe 0 .
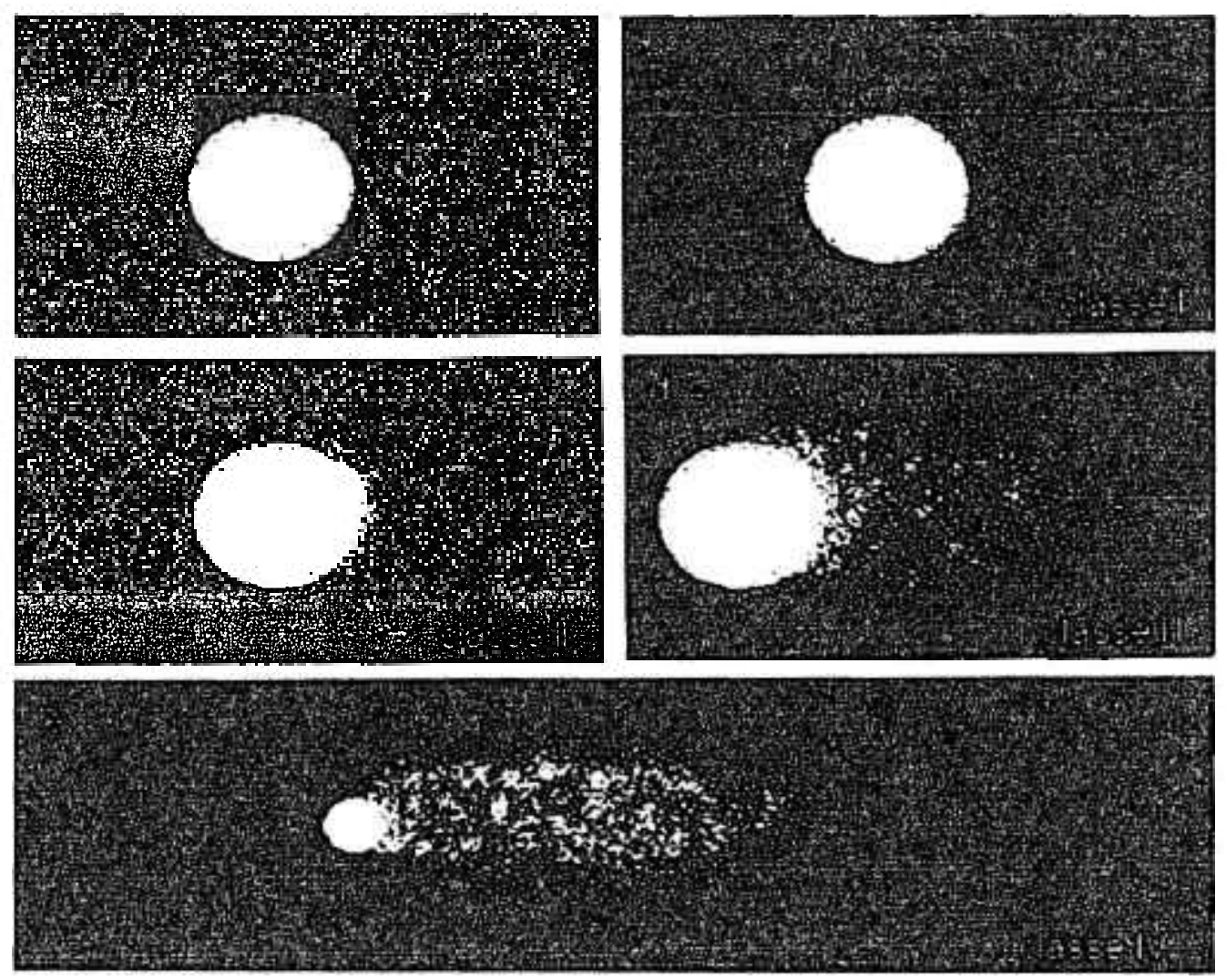

FIGURA 5 - Desenho esquemático da classificação visual dos cometas por categoria de dano a) célula não danificada; b) célula com pouco dano; c) e d) células com muito dano; e) célula extremamente danificada (Nascimento, 2000).

Os valores de DD abrangeram desde situações onde todas as células se mostraram sem dano (classe 0) até aquelas onde todas as células se apresentaram extremamente danificadas (classe IV).

\subsubsection{Ensaio de viabilidade celular}

Um método colorimétrico utilizando MTS e PMS descrito por Chen et al. (1998), Favy et al. (1999) e Glezer et al. (2006) foi adotado para estimar o número de células viáveis expostas à radiação ionizante. 
O ensaio tem como princípio, a avaliação da capacidade de células vivas em reduzir o composto MTS (tetrazolium 3-(4,5-dimetiltiazol-2-yl)-5-(3carboxi-metoxifenil) -2- (4-sulfofenil)-2H-tetrazolium), na presença de um acoplador de elétrons PMS (metossulfeto de fenazina), em um produto formazan solúvel em meio de cultura, graças às enzimas desidrogenases mitocondriais de células metabolicamente ativas (Cory et al., 1991).

A quantidade de produto formazan formado é determinada pela absorvância a $490 \mathrm{~nm}$ e é proporcional ao número de células viáveis em cultura. A principal vantagem desse método é a rapidez na obtenção de dados permitindo a análise de várias amostras ao mesmo tempo.

Células irradiadas com diferentes doses de radiação $(5,10,20$ e 30 Gy) foram semeadas em placa de 96 poços, contendo $1 \times 10^{4}$ células em um volume final de $100 \mu \mathrm{L}$ poço, em respectivo meio de cultivo a $37^{\circ} \mathrm{C}$ e com $5 \%$ de $\mathrm{CO}_{2}$. A densidade celular foi determinada após 120 horas de incubação, adicionando $20 \mu \mathrm{L} /$ poço de solução composta de MTS (2 $\mathrm{mg} / \mathrm{mL}$ de PBS) e PMS (0,92 mg/mL de PBS), na proporção de 20:1. A leitura na absorvância de $490 \mathrm{~nm}$ foi realizada diretamente na placa de 96 poços utilizando um leitor de ELISA, meia hora após a adição do corante.

Neste ensaio, além das linhagens utilizadas nos outros testes foram utilizadas também células $\mathrm{CHO}-\mathrm{K} 1$ (células de ovário de hamster Chinês), amplamente utilizadas nos ensaios de citotoxicidade e genotoxicidade como células referência. Os valores de absorvância obtidos para cada linhagem celular, foram convertidos em porcentagem de redução da viabilidade celular, por meio da adaptação da fórmula descrita por Favy et al. (1999): 


\subsubsection{Análise estatística}

As curvas dose-resposta para indução de micronúcleos e para migração do DNA foram ajustadas pelo modelo linear $(Y=\alpha D)$ onde $Y$ é o número de micronúcleos ou dano ao DNA, a é o coeficiente linear e D é a dose de radiação (Gy).

Para comparação dos dados obtidos entre diferentes linhagens celulares foi utilizado o teste $t$ de Student. Valores de $p<0,05$ foram considerados estatisticamente significativos. Toda a análise estatistica foi feita usando o programa Graph Pad Prism, versão 2,0. 


\section{RESULTADOS}

\subsection{Teste do Micronúcleo}

A análise citogenética de células tumorais e não tumorais, irradiadas com várias doses de ${ }^{60} \mathrm{Co}$ mostrou a presença de um ou mais micronúcleos tanto em células binucleadas como em multinucleadas (Figuras 6 e 7).

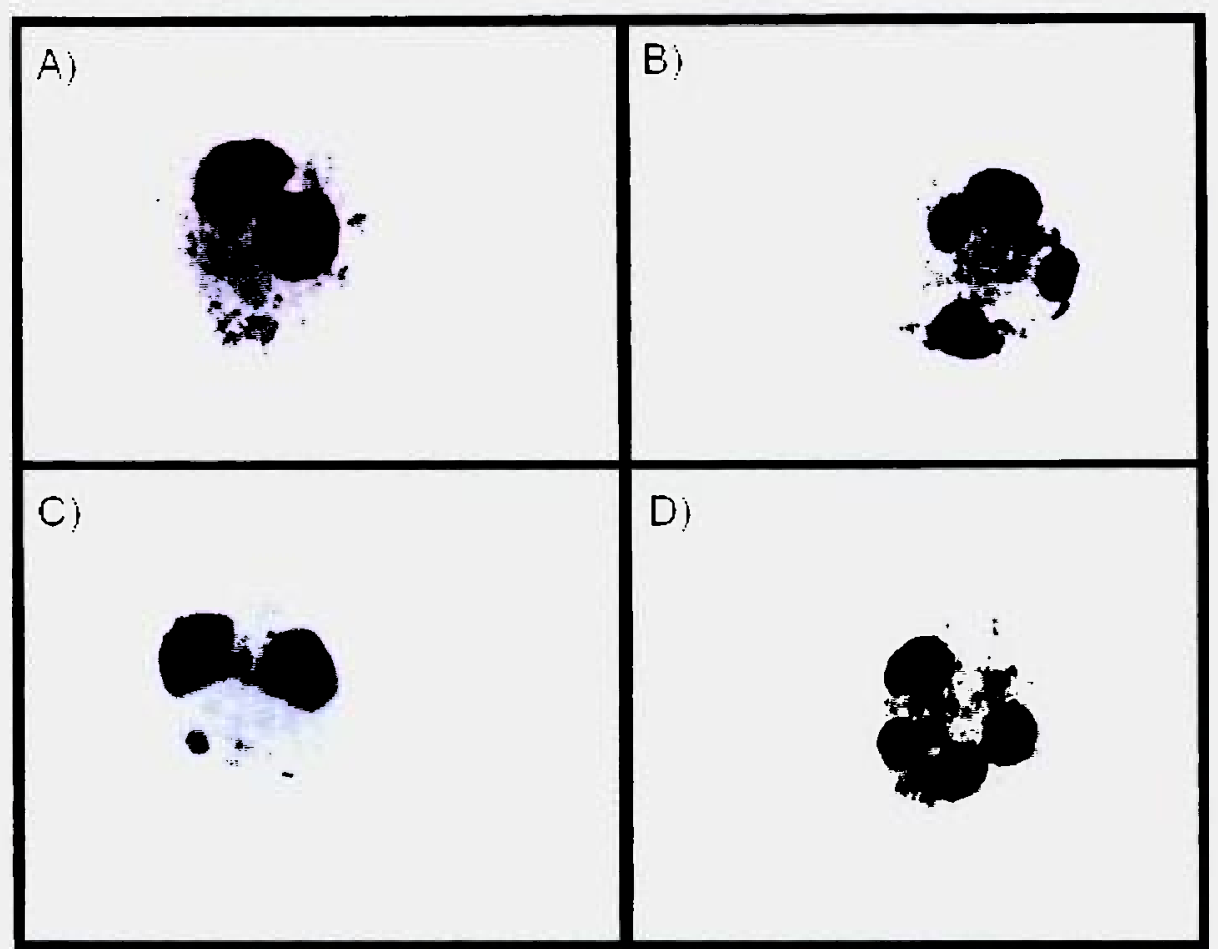

FIGURA 6 - Células tumorais T-47D. A) Célula binucleada, B) Célula multinucleada, C) Célula binucleada com 2 micronúcleos e uma ponte anafásica e D) Célula multinucleada com 1 micronúcleo. 


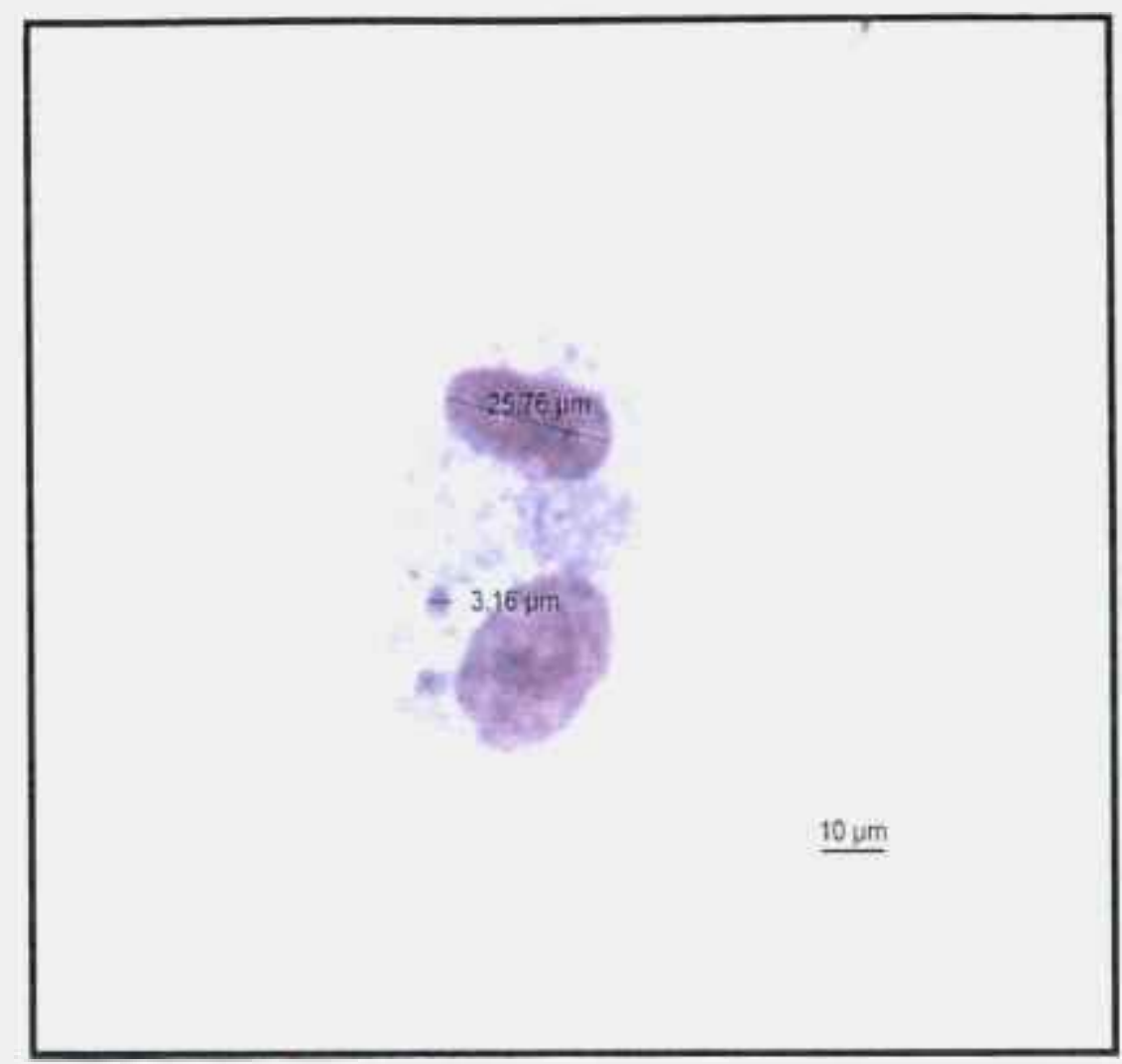

FIGURA 7 - Aspecto morfológico de uma célula T-47D binucleada com dois micronúcleos.

A freqüência e a distribuição de $\mathrm{MN}$ em células binucleadas das três linhagens celulares são apresentadas na tabela 2 e na forma de histograma na figura 8. Pode-se observar um aumento na porcentagem de células binucleadas contendo micronúcleo como também no número de micronúcleos por célula em função da dose de radiação, nas três linhagens celulares. A célula T-47D apresentou uma maior quantidade de danos citogenéticos, seguida das linhagens MCF-7 e MCF-10.

A análise estatística mostrou que há diferença significativa quando se compara valores basais (não irradiados) de MN entre MCF-7 e MCF-10 $(p<0,10)$ ou entre T-47D e MCF-10 tanto para o parâmetro porcentagem de células com MN $(p<0,02)$ como para o parâmetro número de $M N$ por $C B(p<0,005)$, porém não há significância entre T-47D e MCF-7 $(p>0,05)$ para ambos os parâmetros. 
TABELA 2 - Freqüência e distribuição de micronúcleos (MN) em células binucleadas (CB) das linhagens celulares tumorais (MCF-7, T-47D) e não tumorais (MCF-10) de mama humana, irradiadas $\mathrm{com}^{60} \mathrm{Co}$.

\begin{tabular}{ccccccccccc}
\hline $\begin{array}{c}\text { Linhagem } \\
\text { celular }\end{array}$ & $\begin{array}{c}\text { Dose } \\
\text { (Gy) }\end{array}$ & Total de CB & analisadas & 1 & 2 & 3 & 4 & 5 & $\begin{array}{c}\text { CB com MN } \\
\text { (média } \pm \text { desvio }\end{array}$ & $\begin{array}{c}\text { Total MN/CB } \\
\text { (média } \pm \text { desvio } \\
\text { padrão) }\end{array}$ \\
\hline
\end{tabular}

$\begin{array}{lccccccccc} & 0,0 & 2549 & 31 & 9 & 0 & 0 & 0 & 40(1,569 \pm 0,602) & 49(0,019 \pm 0,010) \\ & 0,5 & 2580 & 47 & 9 & 0 & 0 & 0 & 56(2,170 \pm 0,678) & 65(0,025 \pm 0,009) \\ \mathrm{T}-47 \mathrm{D} & 1,0 & 2519 & 82 & 12 & 2 & 0 & 0 & 96(3,811 \pm 0,722) & 112(0,044 \pm 0,003) \\ \mathrm{N}=5 & 2,0 & 2533 & 158 & 30 & 6 & 1 & 0 & 195(7,698 \pm 0,626) & 240(0,095 \pm 0,013) \\ & 4,0 & 2538 & 275 & 85 & 22 & 4 & 0 & 386(15,209 \pm 4,819) & 527(0,208 \pm 0,080) \\ & 5,0 & 2561 & 283 & 124 & 44 & 15 & 4 & 470(18,352 \pm 1,556) & 743(0,290 \pm 0,060)\end{array}$

$\begin{array}{ccccccccccc} & 0,0 & 3004 & 35 & 6 & 1 & 0 & 0 & 42(1,398 \pm 0,738) & 50(0,017 \pm 0,011) \\ & 0,5 & 3031 & 57 & 11 & 0 & 1 & 0 & 69(2,276 \pm 1,272) & 83(0,027 \pm 0,016) \\ \text { MCF-7 } & 1,0 & 3006 & 73 & 19 & 5 & 0 & 0 & 97(3,227 \pm 1,848) & 126(0,042 \pm 0,022) \\ N=6 & 2,0 & 3000 & 115 & 23 & 3 & 0 & 0 & 141(4,700 \pm 1,724) & 170(0,057 \pm 0,020) \\ & 4,0 & 3096 & 190 & 47 & 16 & 4 & 2 & 259(8,366 \pm 2,130) & 358(0,116 \pm 0,032) \\ & 5,0 & 2963 & 208 & 84 & 25 & 9 & 3 & 329(11,104 \pm 3,064) & 502(0,169 \pm 0,061)\end{array}$

$\begin{array}{cccccccccc} & 0,0 & 1559 & 4 & 1 & 0 & 0 & 0 & 5(0,321 \pm 0,115) & 6(0,004 \pm 0,000) \\ & 0,5 & 1544 & 2 & 1 & 0 & 0 & 0 & 3(0,194 \pm 0,200) & 4(0,003 \pm 0,002) \\ \text { MCF-10 } & 1,0 & 1306 & 7 & 1 & 0 & 0 & 0 & 8(0,612 \pm 0,306) & 9(0,007 \pm 0,003) \\ N=3 & 2,0 & 1541 & 11 & 1 & 0 & 0 & 0 & 12(0,779 \pm 0,529) & 13(0,008 \pm 0,006) \\ & 4,0 & 1556 & 10 & 3 & 0 & 0 & 0 & 13(0,835 \pm 0,404) & 16(0,010 \pm 0,006) \\ & 5,0 & 1513 & 15 & 4 & 0 & 0 & 1 & 20(1,322 \pm 0,854) & 28(0,019 \pm 0,011)\end{array}$


A

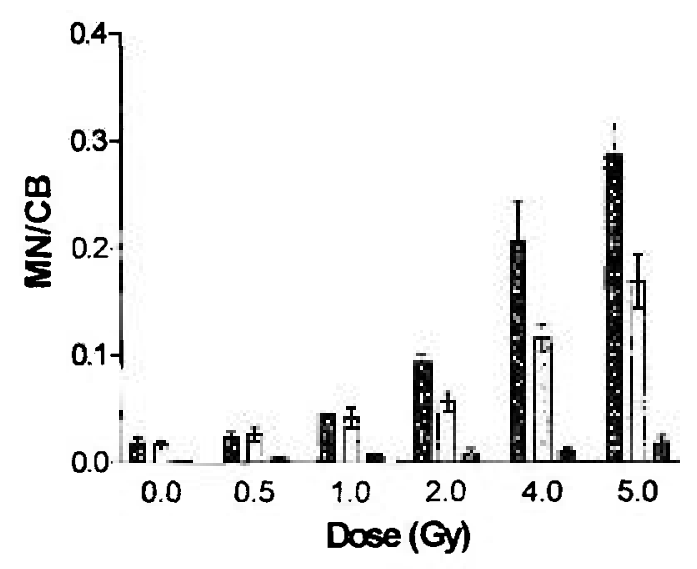

B

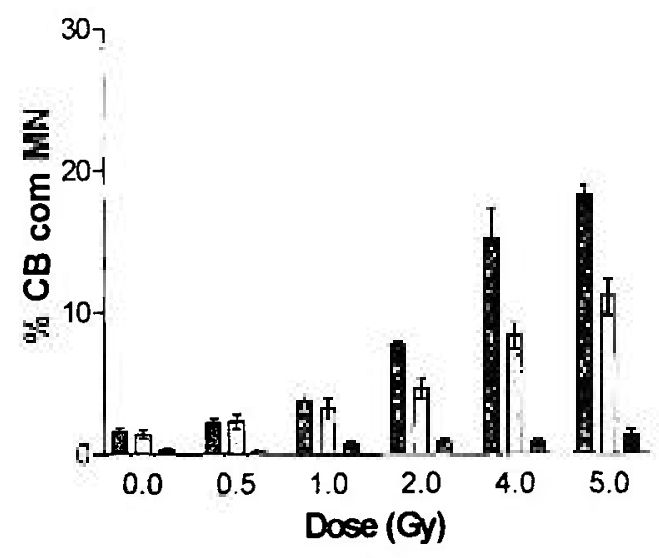

FIGURA 8 - Histogramas mostrando a indução de micronúcleos pela radiação y nas três linhagens celulares: (A) número de micronúcleos por célula binucleada e (B) porcentagem de células binucleadas com micronúcleo.

A relação dose-resposta para indução de $\mathrm{MN}$ está expressa na figura 9 e os valores do coeficiente a do modelo linear usado para ajustar as curvas com seus respectivos desvios-padrão estão apresentados na tabela 3 .

A

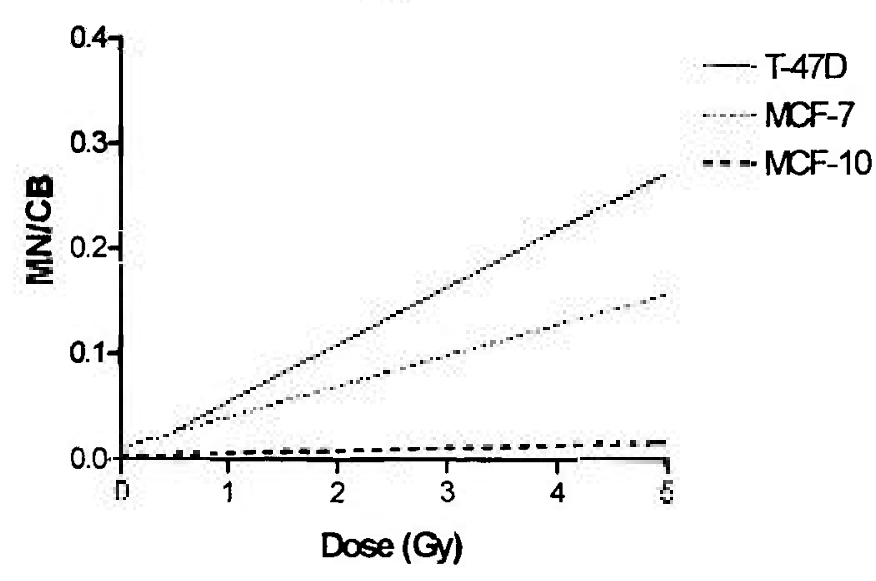

B

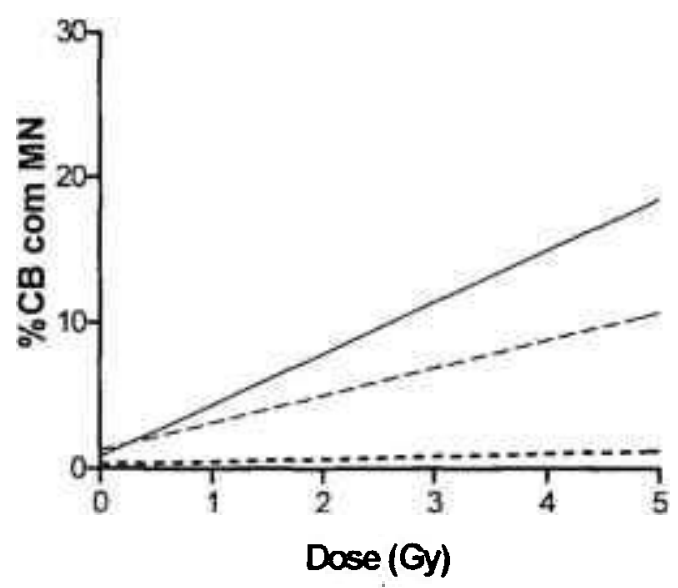

FIGURA 9 - Curvas dosè-resposta para indução de micronúcleos, ajustadas pelo modelo linear das três linhagens celulares: $(A)$ número de micronúcleos por célula binucleada e (B) porcentagem de células binucleadas com micronúcleo. 
TABELA 3 - Valores do coeficiente $\alpha$ do modelo linear $(\gamma=\alpha D)$ utilizado para indução de micronúcleos em três linhagens celulares de mama, irradiadas com várias doses de ${ }^{60} \mathrm{Co}$.

\begin{tabular}{lccc}
\hline Parâmetro & T-47D & MCF-7 & MCF-10 \\
\hline & & & \\
\% de CB com MN & $3,517 \pm 0.202$ & $1,880 \pm 0.167$ & $0,178 \pm 0,056$ \\
$N^{\circ}$ de MN/CB & $0,054 \pm 0.004$ & $0,029 \pm 0.03$ & $0,002 \pm 0,000$ \\
\hline
\end{tabular}

$\mathrm{CB}=$ células binucleadas, $\mathrm{MN}=$ micronúcleos

A tabela 4 apresenta os valores de índice de proliferação (IP) nas três linhagens celulares. Novamente, a linhagem T-47D foi a que apresentou um ciclo celular mais acelerado, seguida de MCF-7 e MCF-10. Houve uma tendência à queda no índice de proliferação com o aumento da dose de radiação nas três linhagens celulares (Fig. 10). A análise estatística mostrou que não há diferença significativa entre MCF-7 e MCF-10 ( $p>0,05)$ no que diz respeito aos valores basais (sem irradiação) de índice de proliferação, porém há diferença quando se compara T-47D em relação à MCF-7 $(p<0,005)$ ou MCF-10 $(p<0,02)$. O teste t mostrou também que não há diferença significativa nos valores de IP em função da dose de radiação $(p>0,05)$ nas três linhagens celulares. 
TABELA 4 - Valores do indice de proliferação nas 3 linhagens celulares, irradiadas com várias doses de ${ }^{60} \mathrm{Co}$.

\begin{tabular}{c|cc|cc|cc}
\hline \multicolumn{2}{|c|}{} & \multicolumn{2}{c|}{ T-47D } & \multicolumn{2}{c|}{ MCF-7 } & \multicolumn{2}{c}{ MCF-10 } \\
\hline $\begin{array}{c}\text { Dose } \\
(\text { Gy) }\end{array}$ & $\begin{array}{c}\text { Total de } \\
\text { células } \\
\text { analisadas }\end{array}$ & $\begin{array}{c}\text { İndice de } \\
\text { proliferação } \\
\text { (média } \pm d p)\end{array}$ & $\begin{array}{c}\text { Total de } \\
\text { células } \\
\text { analisadas }\end{array}$ & $\begin{array}{c}\text { Indice de } \\
\text { proliferação } \\
\text { (média } \pm d p)\end{array}$ & $\begin{array}{c}\text { Total de } \\
\text { células }\end{array}$ & $\begin{array}{c}\text { Indice de } \\
\text { proliferação } \\
\text { analisadas }\end{array}$ \\
\hline 0,0 & 3902 & $1,82 \pm 0,13$ & 5986 & $1,61 \pm 0,06$ & 1410 & $1,53 \pm 0,18$ \\
0,5 & 3801 & $1,83 \pm 0,09$ & 5653 & $1,63 \pm 0,07$ & 1633 & $1,39 \pm 0,16$ \\
1,0 & 3886 & $1,80 \pm 0,16$ & 5730 & $1,61 \pm 0,06$ & 1472 & $1,37 \pm 0,18$ \\
2,0 & 4233 & $1,78 \pm 0,13$ & 5957 & $1,59 \pm 0,02$ & 1637 & $1,41 \pm 0,14$ \\
4,0 & 4258 & $1,77 \pm 0,14$ & 6155 & $1,59 \pm 0,02$ & 1510 & $1,34 \pm 0,14$ \\
5,0 & 4796 & $1,68 \pm 0,15$ & 6225 & $1,57 \pm 0,03$ & 1610 & $1,32 \pm 0,08$ \\
\hline
\end{tabular}

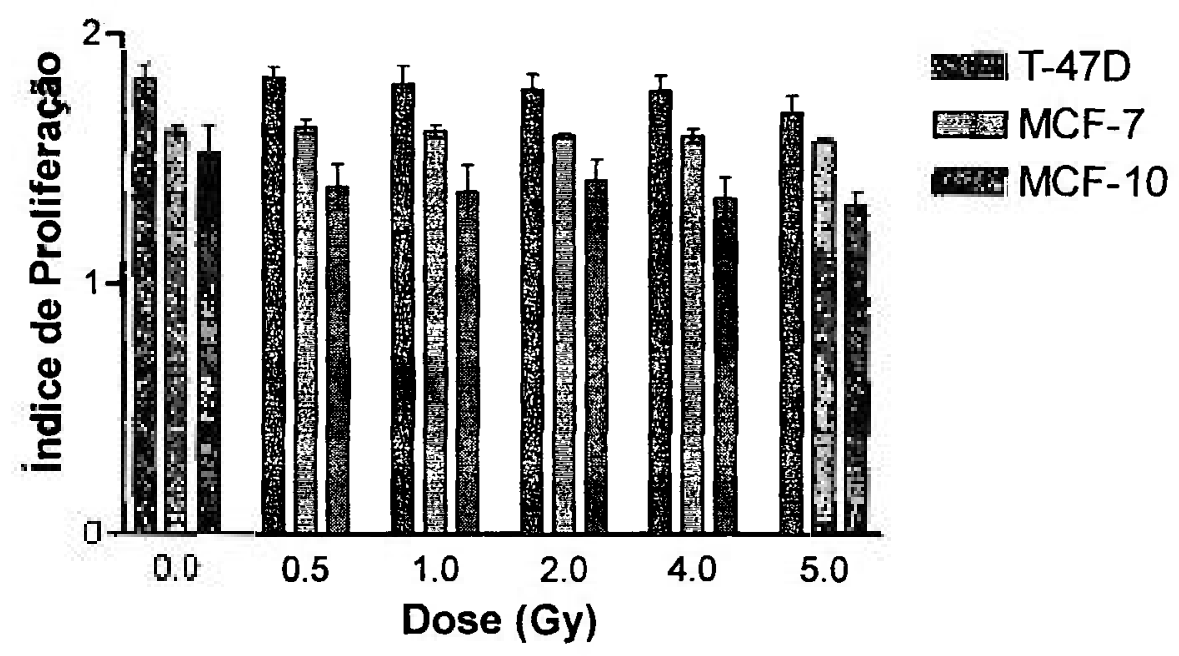

FIGURA 10 - Histograma representando o índice de proliferação encontrado nas três linhagens celulares irradiadas $\mathrm{com}^{60} \mathrm{Co}$. 


\subsection{Teste do Cometa}

O dano radioinduzido e a eficiência de reparo das células tumorais e não tumorais irradiadas foram avaliados pelo teste do cometa, logo após ( $0 \mathrm{~h}$ ), meia hora, uma e três horas após exposição à fonte de ${ }^{60} \mathrm{Co}$. Células não irradiadas mostraram uma matriz nuclear com um halo fluorescente formado pelos filamentos do DNA limitados à área nuclear original (nucleóide). As células irradiadas adquiriram aspectos semelhantes aos cometas, com cabeça e cauda, e cuja extensão da cauda aumentou com a dose de radiação (Figura 11).

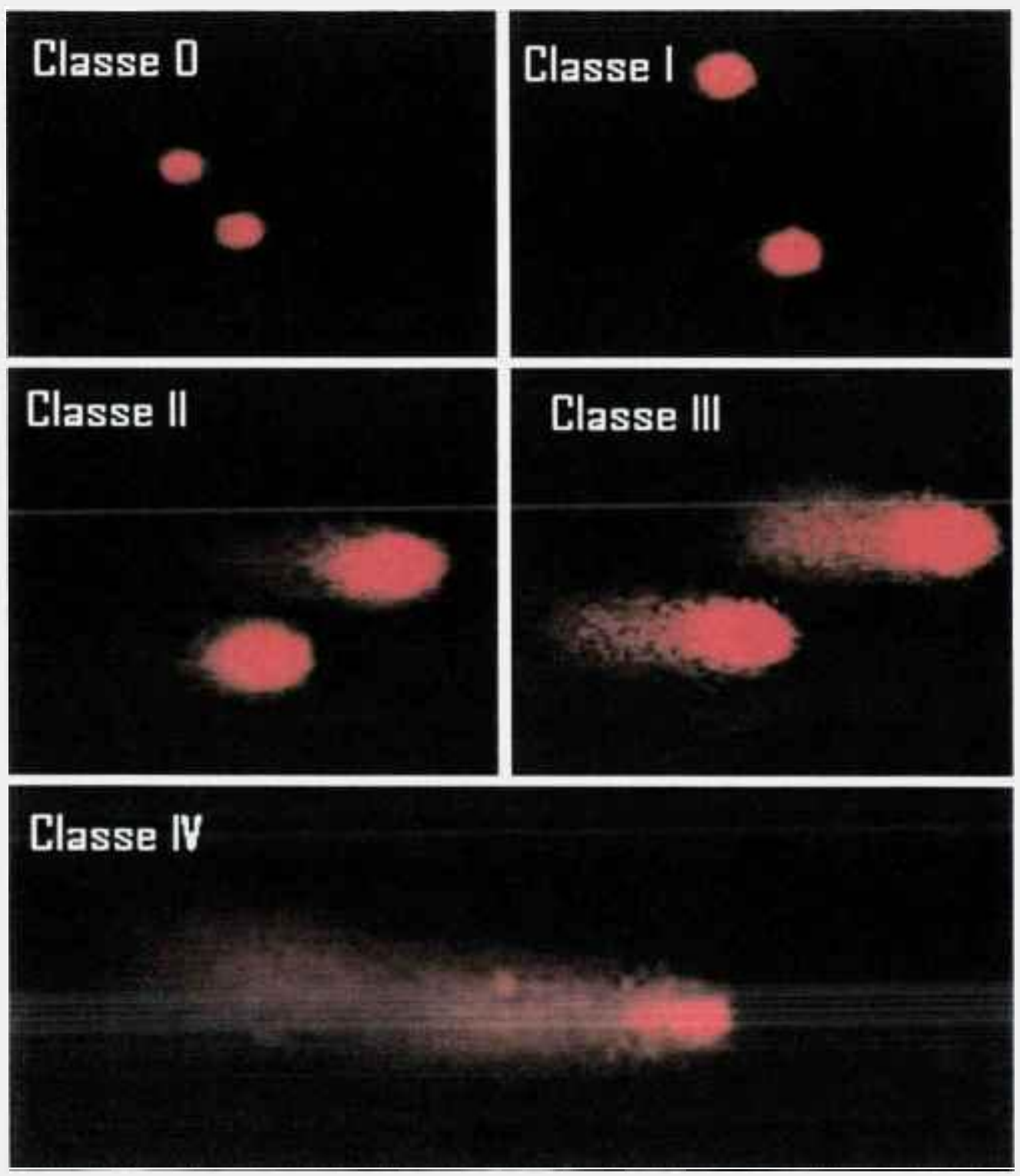

FIGURA 11 - Micrografias de células tumorais T-47D, sem cauda (Classe 0) e com migração do DNA (Classes I,II,III e IV). 
A tabela 5 apresenta os valores de dano ao DNA (DD) de células não irradiadas (controle), obtidas 0 hora, 0,5 hora, 1 e 3 horas de incubação em respectivo meio de cultura. $\mathrm{O}$ teste $\mathrm{t}$ mostrou que não há diferença significativa nos valores basais em relação ao tempo de incubação $(p>0,05)$ para as três linhagens celulares. A análise estatistica mostrou também que não há diferença entre as células T-47D e MCF-7 $(p>0,05)$ quanto aos valores basais, porém quando comparadas com as células MCF-10, o teste t mostrou significância tanto para T-47D $(p<0,005)$ como parar MCF-7 $(p<0,02)$ com menos dano para MCF10.

TABELA 5 - Média dos valores obtidos de amostras controle de células tumorais e não tumorais após diferentes tempos de incubação.

\begin{tabular}{cccccc}
\hline $\begin{array}{c}\text { Linhagem } \\
\text { Celular }\end{array}$ & $\begin{array}{c}\text { Tempo } \\
(\mathrm{h})\end{array}$ & $\begin{array}{c}\text { Total de } \\
\text { células } \\
\text { analisadas }\end{array}$ & $\begin{array}{c}\text { Dano ao } \\
\text { DNA (ua) }\end{array}$ & $\begin{array}{c}\text { Células } \\
\text { com dano } \\
(\%)\end{array}$ & $\begin{array}{c}\text { Células } \\
\text { sem dano } \\
(\%)\end{array}$ \\
\hline T-47D & 0,5 & 150 & $6,67 \pm 4,16$ & 5 & 93 \\
$\mathrm{~N}=3$ & 1 & 150 & $7,33 \pm 8,08$ & 3 & 95 \\
& 3 & 150 & $5,33 \pm 3,06$ & 4 & 96 \\
\hline \multirow{3}{*}{ MCF-7 } & 0 & 150 & $8,00 \pm 4,00$ & 4 & 96 \\
$\mathrm{~N}=3$ & 1 & 150 & $10,00 \pm 6,00$ & 5 & 95 \\
& 3 & 150 & $9,33 \pm 4,16$ & 6 & 94 \\
\hline \multirow{2}{*}{ MCF-10 } & 0,5 & 200 & $2,00 \pm 1,63$ & 2 & 96 \\
$\mathrm{~N}=4$ & 1 & 200 & $1,50 \pm 3,00$ & 1 & 98 \\
& 3 & 200 & $1,50 \pm 1,91$ & 1 & 99 \\
\hline
\end{tabular}

Os resultados obtidos de células irradiadas, analisadas nos diferentes tempos após a exposição estão apresentados na tabela 6 e em forma de 
histograma na figura 12.

Distribuição do dano radioinduzido de acordo com a classificação visual dos cometas em cinco categorias está expressa na tabela 7. A figura 13 mostra as curvas dose-resposta para migração do DNA, ajustadas pelo modelo linear, cujos valores do coeficiente $\alpha$ estão apresentados na tabela 8 .

As células T-47D mostraram uma maior quantidade de dano quando analisadas logo após as exposições em relação a outras linhagens. As células MCF7 e MCF-10 exibiram um comportamento similar. Trinta minutos após, as células T47D continuaram a apresentar valores do DD mais altos em toda a faixa de dose, seguidas de células MCF-10 e MCF-7. Uma hora após, todas as linhagens exibiram uma redução considerável de dano quando comparadas com os valores iniciais. Já após 3 horas, praticamente todo o dano radioinduzido havia sido reparado, restando apenas uma pequena parcela de lesões residuais. Estas observações sugerem uma capacidade de reparo relativamente eficiente das três linhagens estudadas, embora a linhagem MCF-7 tenha mostrado uma capacidade mais rápida de reparar o dano nos primeiros 30 minutos. 
TABELA 6 - Média dos valores de dano ao DNA obtidos de células tumorais e não tumorais de mama, processadas $0 ; 0.5 ; 1$ e $3 \mathrm{~h}$ após a exposição $\mathrm{com}{ }^{60} \mathrm{Co}$.

\section{T-47D}

\section{Dano ao DNA}

Dose $\mathbf{N}^{\circ}$ de

(Gy) células

$\mathbf{O h}$

$0,5 \mathrm{~h}$

1h

$3 \mathbf{h}$

$\mathbf{0 , 0} \quad \mathbf{6 0 0} 9,33 \pm 3,06 \quad 6,67 \pm 4,16 \quad 7,33 \pm 8,08 \quad 5,33 \pm 3,06$

$\mathbf{0 , 5} \quad \mathbf{6 0 0} 29,33 \pm 23,18 \quad 24,00 \pm 11,14 \quad 15,33 \pm 8,33 \quad 14,67 \pm 8,33$

$1,0 \quad 600 \quad 56,67 \pm 45,00 \quad 42,67 \pm 24,68 \quad 15,33 \pm 2,31 \quad 20,00 \pm 27,71$

$\mathbf{2 , 0} \quad 600 \quad 122,67 \pm 38,85 \quad 96,67 \pm 57,49 \quad 39,33 \pm 26,41 \quad 16,67 \pm 9,24$

$4,0 \quad 600 \quad 216,00 \pm 32,92 \quad 200,00 \pm 28,21 \quad 80,67 \pm 73,33 \quad 15,33 \pm 12,86$

$5,0 \quad 600 \quad 257,33 \pm 50,33 \quad 227,33 \pm 30,62 \quad 93,33 \pm 88,82 \quad 28,67 \pm 14,05$

\section{MCF-7}

\section{Dano ao DNA}

Dose

(Gy)

$\mathbf{O} \mathbf{h}$

$0,5 \mathrm{~h}$

$1 \mathrm{~h}$

$3 \mathbf{h}$

$\mathbf{0 , 0} \quad 600 \quad 8,00 \pm 4,00 \quad 10,00 \pm 6,00 \quad 9,33 \pm 4,16 \quad 6,00 \pm 5,29$

$0,5 \quad 600 \quad 26,00 \pm 13,11 \quad 22,00 \pm 11,14 \quad 14,00 \pm 10,39 \quad 14,67 \pm 2,31$

$1,0 \quad 600 \quad 50,67 \pm 19,43 \quad 26,00 \pm 10,00 \quad 39,33 \pm 20,53 \quad 14,00 \pm 13,11$

$2,0 \quad 600 \quad 96,00 \pm 43,86 \quad 50,67 \pm 39,11 \quad 30,67 \pm 34,08 \quad 16,67 \pm 12,06$

$4,0 \quad 600 \quad 153,33 \pm 26,63 \quad 76,00 \pm 53,03 \quad 68,67 \pm 32,39 \quad 14,67 \pm 7,02$

$5,0 \quad 600 \quad 185,33 \pm 51,08 \quad 95,33 \pm 70,47 \quad 92,00 \pm 42,76 \quad 18,00 \pm 13,86$

\section{MCF-10}

\section{Dano ao DNA}

Dose

(Gy)

$\mathbf{O h}$

$0,5 \mathrm{~h}$

$1 \mathrm{~h}$

$3 \mathrm{~h}$

\begin{tabular}{llcccc}
$\mathbf{0 , 0}$ & $\mathbf{8 0 0}$ & $4,50 \pm 2,52$ & $2,00 \pm 1,63$ & $1,50 \pm 0,30$ & $1,50 \pm 1,91$ \\
$\mathbf{0 , 5}$ & $\mathbf{8 0 0}$ & $21,00 \pm 8,87$ & $7,50 \pm 7,55$ & $7,00 \pm 1,15$ & $3,00 \pm 3,83$ \\
$\mathbf{1 , 0}$ & $\mathbf{8 0 0}$ & $\mathbf{4 5 , 0 0 \pm 4 4 , 0 8}$ & $13,00 \pm 15,79$ & $7,50 \pm 5,26$ & $2,50 \pm 3,79$ \\
$\mathbf{2 , 0}$ & $\mathbf{8 0 0}$ & $79,00 \pm 47,00$ & $63,00 \pm 26,15$ & $21,50 \pm 12,48$ & $5,00 \pm 5,77$ \\
$\mathbf{4 , 0}$ & $\mathbf{8 0 0}$ & $155,50 \pm 57,09$ & $133,50 \pm 58,34$ & $64,00 \pm 30,72$ & $23,50 \pm 17,99$ \\
$\mathbf{5 , 0}$ & $\mathbf{8 0 0}$ & $159,50 \pm 59,63$ & $146,00 \pm 37,59$ & $62,00 \pm 28,28$ & $31,50 \pm 22,88$ \\
\hline
\end{tabular}


A

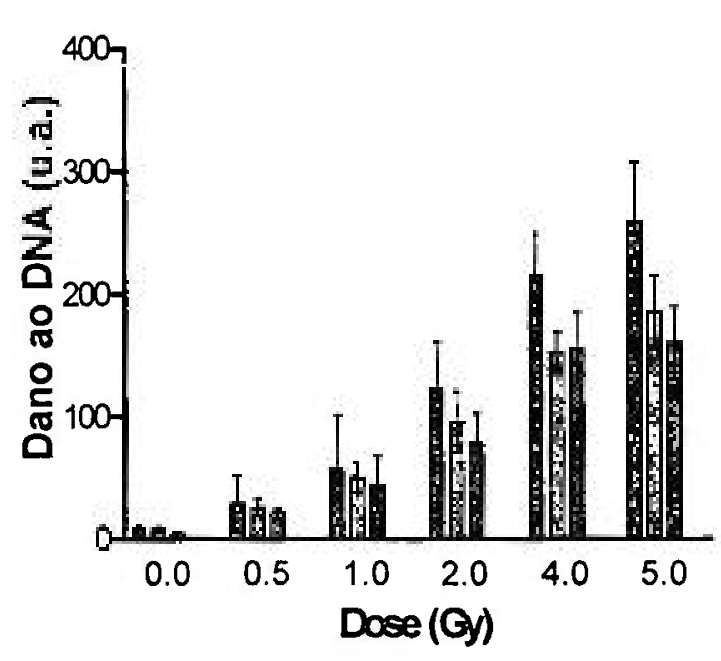

C

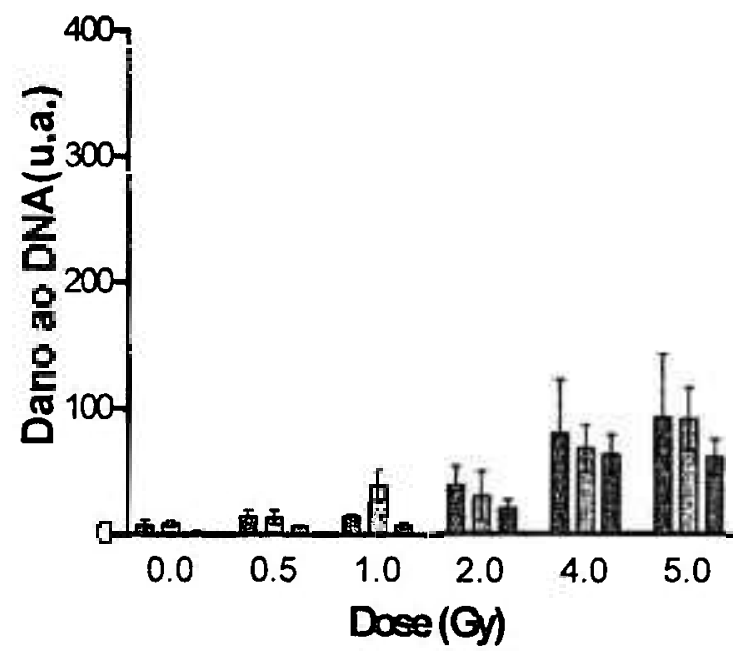

B

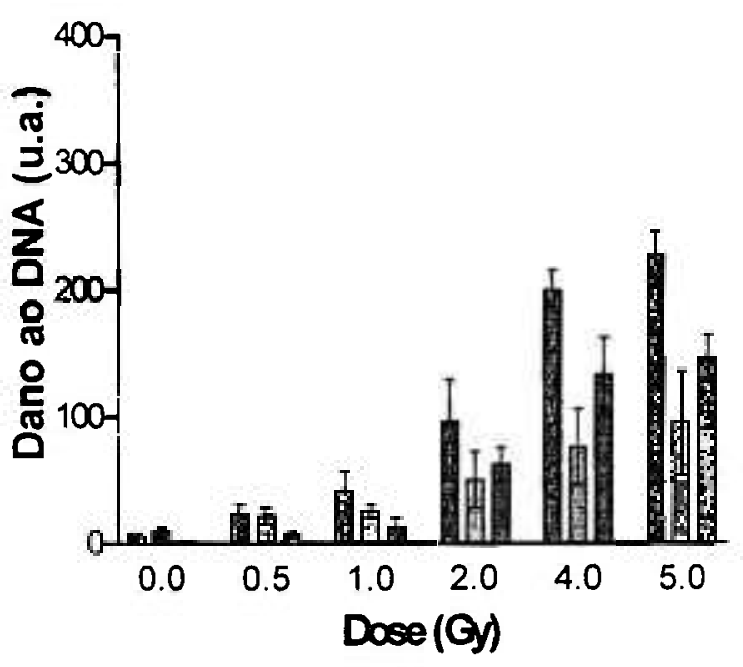

D

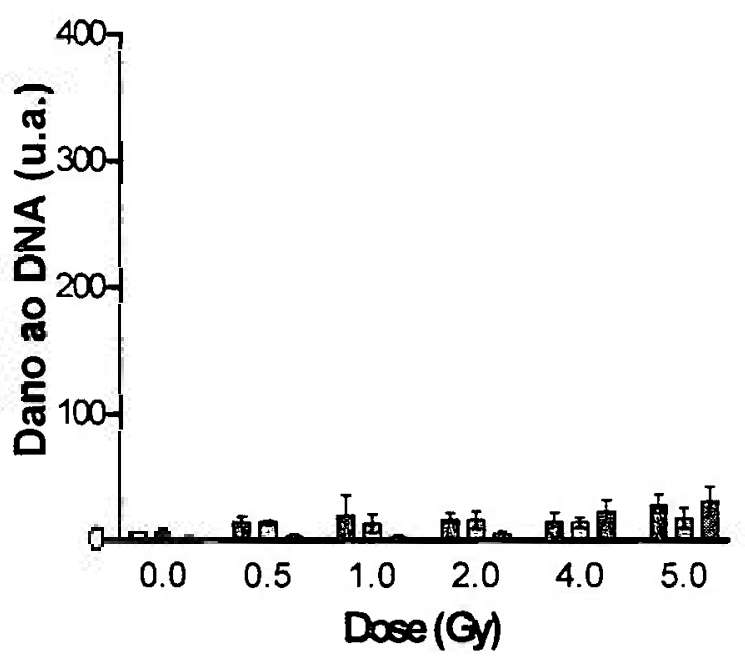

FIGURA 12 - Dano radioinduzido ao DNA de linhagens celulares tumorais e não tumorais, analisadas $0 \mathrm{~h}(\mathrm{~A}), 0.5 \mathrm{~h}(\mathrm{~B}), 1$ (C) e $3 \mathrm{~h}$ (D) após a exposição in vitro à radiação $Y$ de ${ }^{60} \mathrm{Co}$. 
TABELA 7 - Distribuição do dano pela análise de classificação visual (classes 0,1 , II,III e IV) de células tumorais e não tumorais de mama humana processadas $0 ; 0,5 ; 1$ e 3 horas após a exposição in vitro à radiação y de ${ }^{60} \mathrm{Co}$.

\section{T-47D}

\section{0 hora}

0,5 hora

1 hora

3 horas

Dose $\mathrm{N}^{\circ}$ de

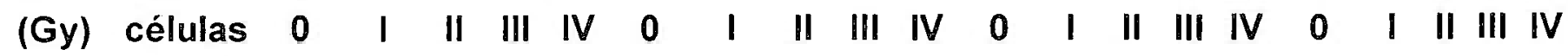
$\begin{array}{llllllllllllllllllllll}0,0 & 600 & 139 & 8 & 3 & 0 & 0 & 143 & 5 & 1 & 1 & 0 & 146 & 0 & 1 & 3 & 0 & 144 & 4 & 2 & 0 & 0\end{array}$ $\begin{array}{llllllllllllllllllllll}0,5 & 600 & 119 & 21 & 8 & 1 & 1 & 132 & 10 & 1 & 4 & 3 & 138 & 7 & 1 & 2 & 2 & 137 & 6 & 5 & 2 & 0\end{array}$ $\begin{array}{llllllllllllllllllllll}1,0 & 600 & 88 & 46 & 12 & 1 & 3 & 104 & 36 & 5 & 2 & 3 & 132 & 14 & 3 & 1 & 0 & 138 & 4 & 1 & 4 & 3\end{array}$ $\begin{array}{llllllllllllllllllllll}2,0 & 600 & 24 & 75 & 45 & 5 & 1 & 51 & 69 & 20 & 4 & 6 & 101 & 41 & 7 & 0 & 1 & 139 & 2 & 4 & 5 & 0\end{array}$ $\begin{array}{llllllllllllllllllllll}4,0 & 600 & 3 & 32 & 71 & 26 & 18 & 0 & 58 & 48 & 29 & 15 & 71 & 42 & 33 & 3 & 1 & 141 & 3 & 2 & 0 & 4\end{array}$ $\begin{array}{llllllllllllllllllllll}5,0 & 600 & 1 & 23 & 45 & 51 & 30 & 0 & 38 & 55 & 38 & 19 & 66 & 37 & 39 & 7 & 1 & 127 & 13 & 3 & 4 & 3\end{array}$

\section{MCF-7}

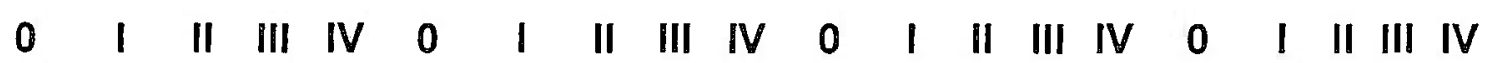
$\begin{array}{llllllllllllllllllllll}\mathbf{0 , 0} & 600 & 144 & 2 & 3 & 0 & 1 & 142 & 5 & 1 & 0 & 2 & 141 & 5 & 3 & 1 & 0 & 144 & 4 & 1 & 1 & 0\end{array}$ $\begin{array}{llllllllllllllllllllll}0,5 & 600 & 128 & 10 & 9 & 1 & 2 & 130 & 13 & 1 & 6 & 0 & 139 & 6 & 1 & 3 & 1 & 139 & 4 & 4 & 3 & 0\end{array}$ $\begin{array}{llllllllllllllllllllll}1,0 & 600 & 114 & 12 & 9 & 14 & 1 & 127 & 15 & 3 & 2 & 3 & 119 & 20 & 7 & 3 & 1 & 140 & 2 & 5 & 3 & 0\end{array}$ $\begin{array}{llllllllllllllllllllll}2,0 & 600 & 61 & 47 & 32 & 7 & 3 & 102 & 35 & 4 & 3 & 6 & 121 & 18 & 7 & 2 & 2 & 135 & 8 & 5 & 1 & 1\end{array}$ $\begin{array}{llllllllllllllllllllll}4,0 & 600 & 15 & 64 & 51 & 16 & 4 & 70 & 57 & 15 & 5 & 3 & 85 & 45 & 9 & 4 & 7 & 139 & 3 & 5 & 3 & 0\end{array}$ $\begin{array}{lllllllllllllllllllllll}\mathbf{5}, 0 & 600 & 5 & 51 & 65 & 19 & 10 & 71 & 42 & 17 & 13 & 7 & 80 & 38 & 11 & 6 & 15 & 139 & 2 & 3 & 5 & 1\end{array}$ MCF-10

$\begin{array}{llllllllllllllllllllll}\mathbf{0 , 0} & 800 & 191 & 9 & 0 & 0 & 0 & 196 & 4 & 0 & 0 & 0 & 198 & 1 & 1 & 0 & 0 & 198 & 1 & 1 & 0 & 0\end{array}$ $\begin{array}{llllllllllllllllllllll}0,5 & 800 & 168 & 26 & 3 & 2 & 1 & 185 & 15 & 0 & 0 & 0 & 188 & 10 & 2 & 0 & 0 & 196 & 3 & 0 & 1 & 0\end{array}$ $\begin{array}{llllllllllllllllllllll}1,0 & 800 & 128 & 57 & 12 & 3 & 0 & 175 & 24 & 1 & 0 & 0 & 187 & 11 & 2 & 0 & 0 & 197 & 2 & 0 & 1 & 0\end{array}$ $\begin{array}{llllllllllllllllllllll}2,0 & 800 & 78 & 96 & 19 & 4 & 3 & 93 & 90 & 15 & 2 & 0 & 162 & 35 & 2 & 0 & 1 & 191 & 7 & 2 & 0 & 0\end{array}$ $\begin{array}{llllllllllllllllllllll}4,0 & 800 & 13 & 91 & 73 & 18 & 5 & 26 & 99 & 61 & 10 & 4 & 95 & 82 & 23 & 0 & 0 & 153 & 42 & 5 & 0 & 0\end{array}$ $\begin{array}{llllllllllllllllllllll}\mathbf{5 , 0} & 800 & 5 & 106 & 63 & 17 & 9 & 10 & 109 & 63 & 15 & 3 & 106 & 67 & 24 & 3 & 0 & 142 & 53 & 4 & 1 & 0\end{array}$ 
A

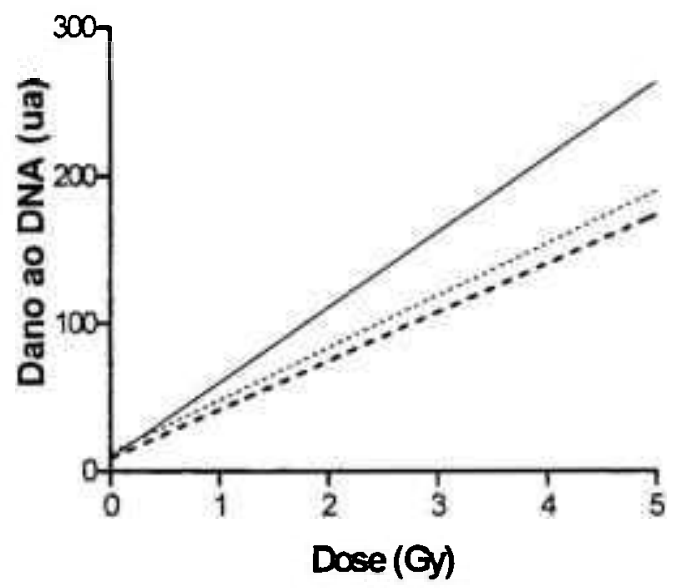

C

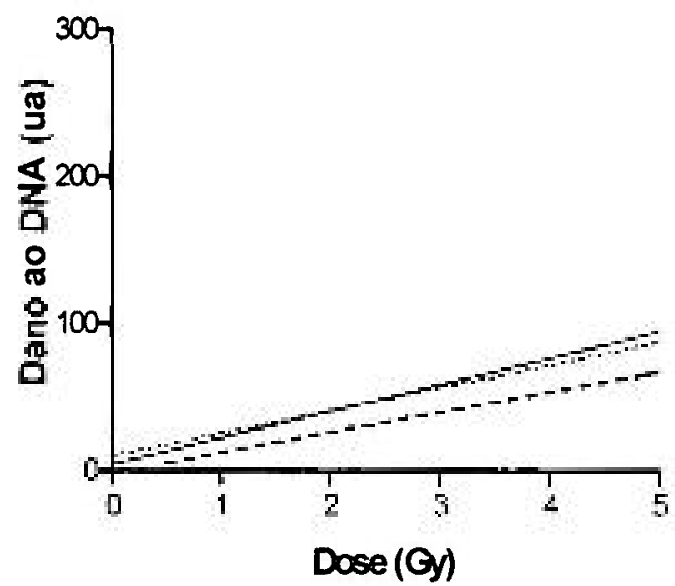

B

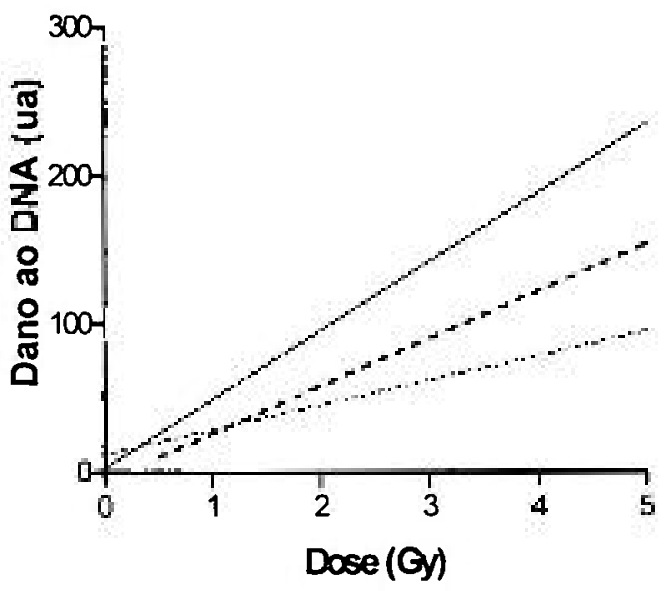

D

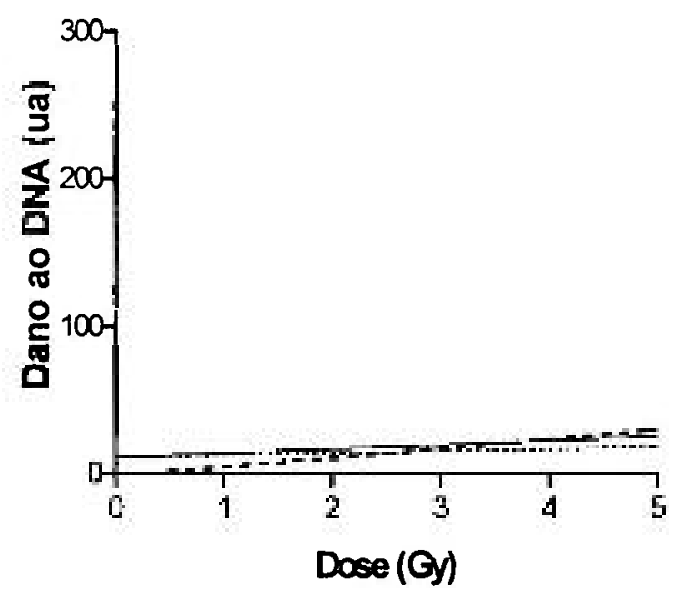

FIGURA 13 - Curvas dose-resposta para indução de dano ao DNA, ajustadas pelo modelo linear obtidas de linhagens celulares tumorais e não tumorais, analisadas $0 \mathrm{~h}$ (A), $0.5 \mathrm{~h}(\mathrm{~B}), 1$ (C) e $3 \mathrm{~h}(\mathrm{D})$ após a exposição in vitro com ${ }^{60} \mathrm{Co}$. 
TABELA 8 - Valores do coeficiente $\alpha$ do modelo linear $(\gamma=\alpha D)$ utilizado para 0 ajuste das curvas dose-resposta para indução de dano ao DNA pelo teste do cometa em linhagens celulares de mama, irradiadas com várias doses de ${ }^{60} \mathrm{Co}$.

\begin{tabular}{cccc}
\hline Tempo de incubação & T-47D & MCF-7 & MCF-10 \\
\hline $0 \mathrm{~h}$ & $50,82 \pm 4,07$ & $35,32 \pm 3,56$ & $32,92 \pm 4,44$ \\
$0,5 \mathrm{~h}$ & $46,53 \pm 3,57$ & $16,61 \pm 4,46$ & $31,98 \pm 3,29$ \\
$1 \mathrm{~h}$ & $18,18 \pm 5,42$ & $15,50 \pm 3,24$ & $13,82 \pm 1,92$ \\
$3 \mathrm{~h}$ & $2,75 \pm 1,76$ & $1,40 \pm 1,18$ & $6,23 \pm 1,29$ \\
\hline
\end{tabular}

\subsection{Teste de Viabilidade Celular}

A figura 14 mostra o perfil de redução da viabilidade celular em função da dose de radiação $\gamma$, para as quatro linhagens celulares, analisadas no quinto dia após as exposições. Á medida que aumentou a dose de radiação, houve uma tendência ao decréscimo no número de células viáveis, com a queda mais acentuada para as células $\mathrm{CHO}-\mathrm{K} 1$.

Entre as linhagens originárias de mama, as células T-47D mostraram-se mais radiossensiveis. As células MCF-7 e MCF-10 apresentaram uma resposta similar em toda a faixa de dose analisada.

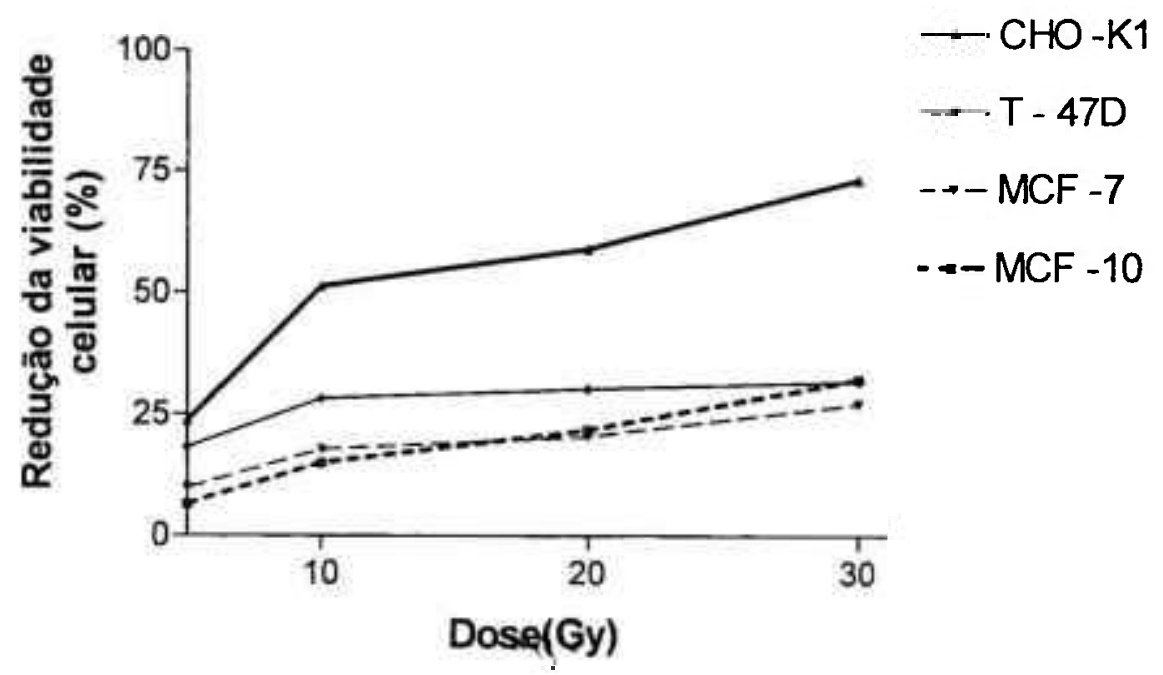

FIGURA 14 - Perfil de redução da viabilidąde celular em função da dose de radiação, avaliada pelo método colorimétrico (MTS-PMS), para as quatro linhagens celulares ęstudadas. 


\section{DISCUSSÃO}

O câncer de mama é uma das doenças fatais mais comuns que acometem uma parcela considerável de mulheres de todo o mundo, particularmente de países industrializados. A radiação ionizante tem sido uma modalidade terapêutica muito difundida no controle do crescimento tumoral. No entanto, poucos são os estudos que focalizam a resposta de células originárias de câncer de mama ao estresse oxidativo, resultante de exposição à radiação ionizante.

De vários tipos de lesões no DNA induzidas pela radiação ionizante, as quebras na fita dupla são consideradas as mais relevantes sob o ponto de vista radiobiológico, isto porque, falha ou erro no reparo de quebra na fita dupla, estão intimamente relacionados com a morte celular, mutação e câncer.

No presente estudo, investigou-se comportamento de linhagens tumorais e não tumorais de mama, com particular ênfase na indução de dano ao DNA, capacidade de reparo e morte celular frente à ação da radiação ionizante.

Os resultados obtidos mostraram que a linhagem não tumoral MCF-10 foi mais radiorresistente que as tumorais (T-47D e MCF-7), evidenciada tanto pela técnica do micronúcleo como pelo teste do cometa. Os dados de danos basais estimados por ambas as técnicas mostraram que a linhagem MCF-10 apresentou menos danos "espontâneos" que as linhagens tumorais. Valores significativamente mais altos de danos basais nas células tumorais sugerem uma instabilidade genômica intrínseca, comuns em células tumorais. Além disso, tratam-se de linhagens celulares mantidas por muitas gerações em condições de cultura.

Das duas linhagens tumorais, a T-47D foi a mais radiossensivel, respondendo com mais intensidade à ação genotóxica da radiação ionizante, com potencial proliferativo significativamente mais alto em relação a demais linhagens, MCF-7 e MCF-10. Quanto mais alta é a taxa proliferativa, maior a probabilidade de acumular erros ou alterações genéticas, o que pode resultar em última instância, numa maior quantidade de danos genéticos em relação às células 
menos proliferativas, quando submetidas à ação de agentes mutagênicos.

No ensaio do cometa, as células T-47D mostraram uma maior radiossensibilidade quando analisadas logo após as exposições $(0 \mathrm{~h})$ em relação às outras linhagens, apresentando uma maior quantidade de danos radioinduzidos. A intensidade de dano ao DNA induzido diretamente após a irradiação é considerada por vários autores ser a responsável para a sensibilidade clínica, porque uma quantidade maior de dano ao DNA terá efeito letal às células (Popanda et al., 2003).

A linhagem MCF-7 exibiu um reparo mais rápido em relação às outras, nos primeiros 30 minutos após a irradiação. No entanto, as três linhagens celulares mostraram uma capacidade de reparo igualmente eficiente $1 \mathrm{~h}$ após a exposição, tendo em vista que a maioria dos danos radioinduzidos havia sido reparada. Após $3 \mathrm{~h}$, as células mostraram uma redução considerável de dano quando comparadas com o valor inicial logo após a exposição com uma pequena quantidade de danos residuais. Segundo Dikomey et al. (2003), danos residuais observados após tratamento com a radiação, são representados pelas quebras na fita dupla não reparadas ou reparadas erroneamente, isto é, lesōes primárias responsáveis pela formação de aberrações cromossômicas ou micronúcleos, observáveis em células na metáfase ou na interfase do ciclo celular, respectivamente.

A Tabela 9 mostra os dados obtidos de três linhagens celulares do presente estudo e àqueles encontrados em linfócitos periféricos de individuos sadios e portadores de câncer de mama, irradiados com ${ }^{60} \mathrm{Co}$ e avaliados pelo teste do cometa (Nascimento et al., 2001). 
TABELA 9 - Valores de dano ao DNA obtidos de linhagens celulares humanas originárias de mama (T-47D, MCF-7 e MCF-10) e de linfócitos periféricos de indivíduos sadios e portadores de câncer de mama, irradiados com ${ }^{60} \mathrm{Co}(0,722 \mathrm{~Gy} / \mathrm{min}$ ) (Nascimento et al., 2001)

\section{Dano ao DNA}

\begin{tabular}{ccccccc}
\hline $\begin{array}{c}\text { Tempo } \\
\text { após a } \\
\text { irradiaçãa } \\
\text { o }\end{array}$ & $\begin{array}{c}\text { Dose } \\
\text { (Gy) }\end{array}$ & T-47D & MCF-7 & MCF-10 & $\begin{array}{c}\text { Linfócitos de } \\
\text { pacientes com } \\
\text { câncer de mama }\end{array}$ & $\begin{array}{c}\text { Linfócitos de } \\
\text { indivíduos sadios }\end{array}$ \\
\hline & 0 & $9,33 \pm 3,06$ & $8,00 \pm 4,00$ & $4,50 \pm 2,52$ & $15,85 \pm 3,27$ & $13,33 \pm 3,06$ \\
Oh & 1 & $56,67 \pm 45,00$ & $50,67 \pm 19,4$ & $45,00 \pm 44,08$ & $158,05 \pm 53,84$ & $207,90 \pm 37,54$ \\
& 2 & $122,67 \pm 38,85$ & $96,00 \pm 43,9$ & $79,00 \pm 47,00$ & $232,18 \pm 16,44$ & $232,46 \pm 11,55$ \\
& 4 & $216,00 \pm 32,92$ & $153,33 \pm 26,63$ & $155,50 \pm 57,09$ & $290,82 \pm 20,10$ & $290,59 \pm 18,34$ \\
\hline & 0 & $5,33 \pm 3,06$ & $6,00 \pm 5,29$ & $1,50 \pm 1,91$ & $14,03 \pm 2,54$ & $10,00 \pm 3,46$ \\
$3 \mathrm{~h}$ & 1 & $20,00 \pm 27,71$ & $14,00 \pm 13,11$ & $2,50 \pm 3,79$ & $84,82 \pm 19,44$ & $55,36 \pm 14,45$ \\
& 2 & $16,67 \pm 9,24$ & $16,67 \pm 12,06$ & $5,00 \pm 5,77$ & $162,17 \pm 55,34$ & $82,67 \pm 11,72$ \\
& 4 & $15,33 \pm 12,86$ & $14,67 \pm 7,02$ & $23,50 \pm 17,99$ & $230,28 \pm 78,26$ & $123,97 \pm 11,12$ \\
& 4 & & & & &
\end{tabular}

Os dados apresentados mostram uma maior quantidade de danos radioinduzidos e uma menor capacidade de reparo dos linfócitos, particularmente de pacientes com câncer de mama, em relação às linhagens celulares do presente estudo. Enquanto os doadores sadios apresentaram uma redução considerável de dano após $3 \mathrm{~h}$, os pacientes mostraram dano residual maior mesmo após $24 \mathrm{~h}$ de exposição (Nascimento et al., 2001), indicando uma capacidade de reparo mais lenta que a dos linfócitos de doadores sadios.

Estes dados mostram uma radiossensibilidade relativamente alta dos linfócitos sanguineos em relação às linhagens originárias de mama, razão pela qual os linfócitos periféricos são rotineiramente utilizados em dosimetria biológica e também em biomonitoramento como um indicador de suscetibilidade dos indivíduos à ação dos mutagênicos ambientais.

Cabe mencionar que nenhuma diferença significativa foi observada nos valores basais das três linhagens celulares no que diz respeito ao tempo de 
incubação $(0,5 \mathrm{~h}, 1$ e $3 \mathrm{~h})$, o que significa que este parâmetro não interferiu na análise dos dados.

Pode-se salientar também que, no presente estudo foi utilizada a classificação visual adotada por Jaloszynski et al. (1997) para a análise dos cometas. Kobayashi et al. (1995) e Mozdarani et al. (2007) relataram que não há diferença estatística entre quantificação visual e análise de imagem por computador utilizando o "tail moment" como parâmetro de avaliação do dano. Da mesma maneira, Nascimento et al. (2001) utilizaram classificação visual e medida do comprimento total do cometa $(\mu \mathrm{m})$ de acordo com McKelvey-Martin et al. (1993) para a avaliação do dano radioinduzido em linfócitos de pacientes com câncer de mama e obtiveram resultados similares. Estas observações permitem concluir que a análise pela classificação visual do cometa, baseada na categoria de dano é um método relativamente rápido, seguro e eficiente.

Entretanto, o teste do cometa apresenta algumas limitações: ele não permite identificar diretamente o tipo de dano e o mecanismo de reparo envolvido e nem a fidelidade com que as lesões no DNA estão sendo reparadas (Popanda et al., 2003). Estudo da cinética de reparo mostrou que ela varia conforme o tipo de lesōes envolvidas. Dano de base e quebra na fita simples são geralmente reparadas com alta fidelidade dentro de primeiros 15 minutos após a irradiação, desde que a fita não danificada do DNA com sua seqüência de base complementar possa ser usada como "template" para reparar. Todavia, o reparo torna-se mais difícil para a quebra na fita dupla onde ambas as fitas do DNA são afetadas aparentemente no mesmo sítio e pode levar de 2 - $3 \mathrm{~h}$ para reparar (Singh et al., 1988; Price, 1993; Tice, 1995; Hill, 1999; Popanda et al., 2003). Segundo Hill (1999), de modo geral, mais de $90 \%$ das quebras da fita dupla induzidas pela radiação y são reparadas em $3 \mathrm{~h}$; já as quebras na fita dupla produzidas pelas particulas a podem ser reparadas com uma redução de 30 - 50 $\%$ após $3 \mathrm{~h}$.

As células de mamiferos adotam preferencialmente a rota de rejunção de extremidades não homólogas (NHEJ) para reparar quebras ocorridas na fita dupla induzidas pela radiação ionizante, apesar desta rota estar sujeito a erro 
("error-prone") e causar freqüentemente pequenas deleçōes do DNA (Dikomey et al., 2003; Trenz et al., 2005; Kan'o et al., 2007). Em contraste, o reparo por recombinação homóloga $(\mathrm{HR})$ requer homologia extensiva para restaurar a molécula do DNA e, portanto, o processo de reparo é efetuado com maior fidelidade, livre de erro (error-free) (Taylor \& Lehmann, 1998; Hill, 1999; Dikomey et al., 2003; Sankaranarayanan, 2006) Com base nestas observações, possiveis deleções oriundas do próprio mecanismo de reparo via NHEJ, podem também contribuir para a formação de micronúcleos. Há possibilidade também da indução de novas quebras nas fitas simples e duplas do DNA durante o próprio processo de reparo celular, a partir de bases alteradas (Pouget e Mather, 2001)

A despeito das três linhagens celulares apresentarem uma capacidade de reparo similar $3 \mathrm{~h}$ após a exposição, as células T-47D mostraram uma quantidade significativamente maior de micronúcleos em relação às outras linhagens. Em vista do lapso de tempo relativamente longo entre a indução de dano pela radiação e a expressão de um fenótipo celular alterado, muitas vezes, é dificil de estabelecer uma relação de causa e efeito. Contudo, uma possível explicação pode ser o seu próprio "status" do p53 (Siles et al., 1996).

Estudo de seqüenciamento de DNA tem mostrado que as células T47D apresentam uma mutação no códon 194 (exon 6) do gene p53, com alteração de leucina (CTT) para fenilalanina (TTT), dentro da região de "binding" do DNA, enquanto as células MCF-7 e MCF-10 expressam p53 selvagem (Bartek et al., 1990; Keane et al., 1999; Butt et al., 2000, Lacroix et al., 2006). Mutações gênicas do tipo "missense" são freqüentemente encontradas ( 90\%) na maioria dos casos de câncer de mama (Bartek et al., 1990). Outros tipos de mutações como pequenas deleções, inserções e mutações gênicas "nonsense" são também observadas, porém em proporções menores.

O p53 exerce seu efeito como supressor tumoral por meio do controle da proliferação celular, levando a um bloqueio na fase $\mathrm{G} 1$ do ciclo celular pela transativação do p21 que inibe as kinases dependentes de ciclina após a exposição com agentes genotóxicos. É relatado uma íntima associação temporal entr o aumento dos níveis da proteína p53 intracelular e bloqueio no G1 após 
irradiação (Kastan et al., 1991). Em contraste, as células com o gene p53 mutado não mostram qualquer aumento nos níveis desta proteína após o dano ao DNA, o que sugere o envolvimento da proteina p53 na falha do bloqueio no G1 (Silas et al., 1996).

De fato, estudos realizados têm mostrado que a linhagem T-47D bem como as células $\mathrm{CHO}-\mathrm{K} 1$, ambas mutantes de $\mathrm{p} 53$, não exibiram bloqueio na fase GO/G1 do ciclo celular, mas sim um aumento de células em G2/M quando expostas aos raios $X$, indicando uma falha no "checkpoint" no $G 1$ (Siles et al., 1996; Hu et al., 1999; Butt et al., 2000).

Por outro lado, as células MCF-7, que expressam p53 selvagem mostraram um aumento inicial nos níveis da proteína p53 intracelular com valores máximos $4 \mathrm{~h}$ após a irradiação com ${ }^{60} \mathrm{Co}$, com o bloqueio concomitante na fase G0/G1 do ciclo celular (Siles et al., 1996). O "checkpoint" retarda a progressão do ciclo celular por permitir o reparo. Estas informaçōes nos permitem associar a taxa proliferativa relativamente alta encontrada em células T-47D com a falha do "checkpoint" em resposta à radiação ionizante.

No entanto, a capacidade de reparo da linhagem T-47D não foi significativamente afetada, apesar de ser um mutante de p53. Esta aparente incongruência pode ser explicada pelo fato do p53 participar no reparo do DNA, via rota de excisão de base ou de nucleotideo (Starcevic et al., 2003) e provavelmente, não na rota de reparo de quebra na fita dupla.

Os ensaios de viabilidade celular utilizando o teste do MTS-PMS mostraram que as células $\mathrm{CHO}-\mathrm{K} 1$ responderam de maneira pronunciada à ação da radiação ionizante, seguida de células $T-47 D$ com uma radiossensibilidade mais acentuada em relação à MCF-7 e MCF-10. O resultado obtido pode ser um reflexo da quantidade relativamente alta de células danificadas (\% de células binucleadas com micronúcleo) com lesões intracelulares mais intensas (número de micronúcleos/célula binucleada) encontradas na linhagem T-47D, o que pode ter resultado numa letalidade mais alta.

O teste empregado, no entanto, não permite identificar a modalidade de morte celular envolvida, isto é, se ocorre por processo apoptótico ou necrótico. 
Vários autores (Dewey et al., 1995; Hu et al., 1999; Murakami et al., 2004) verificaram que as células $\mathrm{CHO}-\mathrm{K} 1$ e $\mathrm{CHO}-\mathrm{WBL}$, ambas mutantes de p53, com a proteina p53 alterada e com falha no "checkpoint", morrem predominantemente pelo processo necrótico.

É reconhecido que as células tumorais de mama são geralmente resistentes à apoptose (Starcevic et al., 2003). A análise do DNA genômico por meio da eletroforese de gel de agarose tem mostrado que a linhagem T-47D é relativamente resistente à apoptose, ao passo que a MCF-7, suscetível à apoptose radioinduzida (Siles et al., 1996; Butt et al., 2000). Embora a perda da função do p53 possa anular o bloqueio celular na fase $\mathrm{G1}$, a apoptose radioinduzida pode também ocorrer em linhagens tumorais humanas por um mecanismo independente de p53 (Bracey et al., 1995).

Há relatos de que a perda da função do p53 como nos casos de mutantes de p53 aumenta a resistência aos agentes genotóxicos em linhagens tumorais humanas (Starcevic et al., 2003). Estas observaçōes, no entanto, não condizem com o presente estudo, tendo em vista que a linhagem T-47D, mutante de $p 53$, foi a mais radiossensivel. A radiossensibilidade celular é uma característica multifatorial e é pouco provável que haja um só fator determinante para explicar uma gama variada de sensibilidade encontrada em células de mamiferos.

A despeito de uma quantidade considerável de trabalhos publicados, os mecanismos celulares e moleculares responsáveis pela radiossensibildiade celular ou individual, não estão ainda totalmente elucidados.

Contudo, há vários estudos que apontam alguns fatores como os responsáveis pela radiossensibilidade intrínseca de células humanas, por exemplo, quantidade inicial de danos ocorridos ao DNA, particularmente, quebra na fita dupla; número de quebra na fita dupla não reparada; taxa e fidelidade da rejunção da quebra na fita dupla; alterações na progressão do ciclo celular e apoptose (Kastan et al., 1992; Siles et al., 1996; Dikomey \& Brammer, 2000; Li et al., 2001; Dikomey et al., 2003; Kan' o et al., 2007). 
Os resultados obtidos no presente estudo referem-se a poucas linhagens celulares analisadas. Obviamente, outras investigações são necessárias com o emprego de diferentes metodologias, envolvendo aspectos morfológico, bioquímico e/ou molecular, para uma avaliação mais acurada dos fenômenos biológicos envolvidos. 


\section{CONCLUSÕES}

Os dados obtidos sobre indução de dano, capacidade de reparo e morte celular em linhagens celulares tumorais (T-47D e MCF-7) e não tumorais (MCF-10) de mama humana, irradiadas com várias doses de ${ }^{60} \mathrm{Co}$ avaliados por meio dos testes do micronúcleo, cometa e viabilidade celular, permitiram concluir que:

$>$ As linhagens tumorais foram mais radiossensiveis que a linhagem não tumoral em todos os testes utilizados;

$>$ A linhagem T-47D, foi a que apresentou uma maior quantidade de dano, frente à radiação ionizante e também foi a que apresentou um ciclo celular mais acelerado, seguida das linhagens MCF-7 e MCF-10;

> A linhagem MCF-10 apresentou menos danos "espontâneos" (dano basal) em forma de $\mathrm{MN}$ em relação às linhagens tumorais;

$>$ As três linhagens celulares apresentaram uma capacidade de reparo relativamente eficiente, tendo em vista que o reparo foi completado dentro de 3 horas após a irradiação;

$>$ Não foram observadas diferenças significativas nos valores basais referentes aos diferentes tempos de incubação, o que indica que este parâmetro não interferiu na análise dos dados;

$>\mathrm{O}$ teste de viabilidade celular mostrou que a célula $\mathrm{CHO}-\mathrm{K} 1$ foi a mais afetada frente à radiação ionizante, seguida de linhagem tumoral T-47D. As linhagens MCF-7 e MCF-10 mostraram respostas similares;

$>$ Os testes empregados mostraram ser uma ferramenta valiosa que permitiu quantificar e avaliar danos radioinduzidos, capacidade de reparo e morte celular nas três linhagens celulares analisadas. 


\section{REFERÊNCIAS BIBLIOGRÁFICAS}

ALBERTS, B. J., A.; LEWIS, J.; RAFF, M.; ROBERTS, K.; WALTER P. Molecular Biology on the Cell. New York: Garland Science, 2002.

BARTEK, J., R. IGGO, J. GANNON \& D. P. LANE. Genetic and immunochemical analysis of mutant p53 in human breast cancer cell lines. Oncogene, v.5, n.6, p.893-9, 1990.

BENNETT, M. R. Mechanisms of p53-induced apoptosis. Biochemical Pharmacology, v.58, n. 7, p.1089-95, 1999.

BLASIAK, J., M. ARABSKI, R. KRUPA, K. WOZNIAK, J. RYKALA, A. KOLACINSKA, Z. MORAWIEC, J. DRZEWOSKI \& M. ZADROZNY. Basal, oxidative and alkylative DNA damage, DNA repair efficacy and mutagen sensitivity in breast cancer. Mutation Research v.554, n 1-2, p.139-48, 2004.

BRACEY, T. S., J. C. MILLER, A. PREECE \& C. PARASKEVA. Gamma-radiationinduced apoptosis in human colorectal adenoma and carcinoma cell lines can occur in the absence of wild type p53. Oncogene, v.10, n.12, p.2391-6, 1995.

BUTT, A. J., S. M. FIRTH, M. A. KING \& R. C. BAXTER. Insulin-like growth factorbinding protein-3 modulates expression of $\mathrm{Bax}$ and $\mathrm{Bcl}-2$ and potentiates p53independent radiation-induced apoptosis in human breast cancer cells. Journal Biological Chemmistry, v.275, n. 50, p. 39174-81, 2000.

CHEN, T. J., C. B. KUO, K. F. TSAI, J. W. LIU, D. Y. CHEN \& A. M. WALKER. Development of recombinant human prolactin receptor antagonists by molecular mimicry of the phosphorylated hormone. Endocrinology, v.139, n. 2, p.609-16, 1998.

CORY, A. H., T. C. OWEN, J. A. BARLTROP \& J. G. CORY. Use of an aqueous soluble tetrazolium/formazan assay for cell growth assays in culture. Cancer Communication, v. 3, n. 7, p.207-12, 1991.

DEWEY, W. C., C. C. LING \& R. E. MEYN. Radiation-induced apoptosis: relevance to radiotherapy. International Journal Radiation Oncology Biology Physics, v.33, n.4, p.781-96, 1995.

DIKOMEY, E. \& I. BRAMMER. Relationship between cellular radiosensitivity and non-repaired double-strand breaks studied for different growth states, dose rates and plating conditions in a normal human fibroblast line. International Journal Radiation Biology, v.76, n.6, p.773-81, 2000.

DIKOMEY, E., K. BORGMANN, I. BRAMMER \& U. KASTEN-PISULA. Molecular mechanisms of individual radiosensitivity studied in normal diploid human fibroblasts. Toxicology, v.193, n. 1-2, p.125-35, 2003. 
FAVY, D. A., P. RIO, J. C. MAURIZIS, C. HIZEL, Y. J. BIGNON \& D. J. BERNARD-GALLON. Prolactin-dependent up-regulation of BRCA1 expression in human breast cancer cell lines. Biochemical Biophysical Research Communications, v.258, n.2, p.284-91, 1999.

FENECH, M. \& MORLEY, A. A. Measurement of micronuclei in lymphocytes. Mutation Research, v.147, n.1-2, p.29-36, 1985.

. Cytokinesis-block micronucleus method in human lymphocytes: effect of in vivo ageing and low dose X-irradiation. Mutation Research, v.161, n.2, p.193-8, 1986.

FUTREAL, P. A., Q. LIU, D. SHATTUCK-EIDENS, C. COCHRAN, K. HARSHMAN, S. TAVTIGIAN, L. M. BENNETT, A. HAUGEN-STRANO, J. SWENSEN \& $Y$. MIKI BRCA1 mutations in primary breast and ovarian carcinomas. Science, v.266, n.5182, p.120-2, 1994.

GATTI, R. A., K. L. PETERSON, J. NOVAK, X. CHEN, L. YANG-CHEN, T. LIANG, E. LANGE \& K. LANGE. Prenatal genotyping of ataxia-telangeictasia. Lancet, v.342 (8867), p.376, 1993.

GLEZER, A., C. R. SOARES, J. G. VIEIRA, D. GIANNELLA-NETO, M. T. RIBELA, V. GOFFIN \& M. D. BRONSTEIN. Human macroprolactin displays low biological activity via its homologous receptor in a new sensitive bioassay. Journal of Clinical Endocrinology \& Metabolism, v.91, n.3, p.1048-55, 2006.

HALL, E. J. A radiation biologist looks to the future. International Journal Radiatiation Oncology Biology Physics, v.46, n.1, p.1-2, 2000.

HALL, J. M., M. K. LEE, B. NEWMAN, J. E. MORROW, L. A. ANDERSON, B. HUEY \& M. C. KING. Linkage of early-onset familial breast cancer to chromosome 17q21. Science, v.250, n.4988, p.1684-9, 1990.

HANCOCK, R. Packing of the polynucleosome chain in interphase chromosomes: evidence for a contribution of crowding and entropic forces. Seminars in cell \& developmental biologyv.18, N.5, p.668-75, 2007.

HELZLSOUER, K. J., E. L. HARRIS, R. PARSHAD, S. FOGEL, W. L. BIGBEE \& K. K. SANFORD. Familial clustering of breast cancer: possible interaction between DNA repair proficiency and radiation exposure in the development of breast cancer. International Journal Cancer, v.64, n.1, p.14-7, 1995.

HILL, M. A. Radiation damage to DNA: the importance of track structure. Radiation Measurements, v.31, n.1-6, p.15-23, 1999.

HOEIJMAKERS, J. H. Genome maintenance mechanisms for preventing cancer. Nature, v. 411, n. 6835, p. 366-74, 2001. 
HU, T., C. M. MILLER, G. M. RIDDER \& M. J. AARDEMA. Characterization of p53 in Chinese hamster cell lines CHO-K1, CHO-WBL, and $\mathrm{CHL}$ : implications for genotoxicity testing. Mutation Research, v.426, n.1, p.51-62, 1999.

INSTITUTO NACIONAL DE CÂNCER (INCA/PRO-ONCO) - MINISTÉRIO DA SAÚDE. Estimativa da incidência e mortalidade por câncer no Brasil 2008. Rio de Janeiro, 2008.

INTERNATIONAL ATOMIC ENERGY AGENCY. Technical Report Series, Cytogenetics analysis for radiation dose assessment: a manual. IAEA, Vienna,2001.

JACKSON, S. P. Sensing and repairing DNA double-strand breaks. Carcinogenesis, v. 23, n. 5, p. 687-96, 2002.

JALOSZYNSKI, P., M. KUJAWSKI, M. CZUB-SWIERCZEK, J. MARKOWSKA \& K. SZYFTER. Bleomycin-induced DNA damage and its removal in lymphocytes of breast cancer patients studied by comet assay. Mutation Research, v.385, n.3, p.223-33, 1997.

JAMEEL, J. K., V. S. RAO, L. CAWKWELL \& P. J. DREW. Radioresistance in carcinoma of the breast. Breast, v. 13 n.6, p.452-60, 2004.

KAN'O, M., T. KAWATA, H. ITO, N. SHIGEMATSU, C. LIU, T. UNO, K. ISOBE, H. KAWAKAMI, F. CUCINOTTA, K. GEORGE \& A. KUBO. Repair of potentially lethal damage in normal cells and ataxia telangiectasia cells; consideration of nonhomologous end-joining. Journal Radiation Research (Tokyo), v. 48, n.1, p. 31$8,2007$.

KASTAN, M. B., O. ONYEKWERE, D. SIDRANSKY, B. VOGELSTEIN \& R. W. CRAIG. Participation of $p 53$ protein in the cellular response to DNA damage. Cancer Research, v.51, n.23, p.6304-11, 1991.

KEANE, M. M., S. A. ETTENBERG, M. M. NAU, E. K. RUSSELL \& S. LIPKOWITZ. Chemotherapy augments TRAIL-induced apoptosis in breast cell lines. Cancer Research, v. 59, n.3, p. 734-41, 1999.

KEY, T. J. Hormones and cancer in humans. Mutation Research, v. 333, n. 1-2, p. 59-67, 1995.

KHANNA, K. K. \& CHENEVIX-TRENCH, G. ATM and genome maintenance: defining its role in breast cancer susceptibility. Journal Mammary Gland Biology Neoplasia, v. 9, n. 3, p. 247-62, 2004.

KHANNA, K. K. \& JACKSON, S. P. DNA double-strand breaks: signaling, repair and the cancer connection. Nature Genetics, v.27, n. 3, p.247-54, 2001. 
KOBAYASHI, H. S., C.; MORIKAWA, Y.; HAYASHI, M. \& SOFUNI, T. A comparison between manual microscopic analysis and computerized image analysis in the single cell gel electrophoresis. MMS Communication, v.3, p.103115, 1995.

KONDO, S. Mutation and cancer in relation to the atomic-bomb radiation effects. Japanese Journal Cancer Research, v.79, n.7, p.785-99, 1988.

KOTSOPOULOS, J., Z. CHEN, K. A. VALLIS, A. POLL, P. AINSWORTH \& S. A. NAROD. DNA repair capacity as a possible biomarker of breast cancer risk in female BRCA1 mutation carriers. British Journal of Cancer, v.96, n.1, p.118-25, 2007.

LACROIX, M., R. A. TOILLON \& G. LECLERCQ. p53 and breast cancer, an update. Endocrine Related Cancer, v.13, n.2, p.293-325, 2006.

LEE, H., J. M. LARNER \& J. L. HAMLIN. Cloning and characterization of Chinese hamster p53 cDNA. Gene, v.184, n.2, p.177-83, 1997.

MACHADO, C. R. \& MENCK, C. F. M. Human DNA repair diseases: from genoma instability to cancer. Brazilian Journal Genetics, v.20, p.755-762, 1997.

MAMON, H. J., W. DAHLBERG, E. I. AZZAM, H. NAGASAWA, M. G. MUTO \& J. B. LITTLE. Differing effects of breast cancer 1 , early onset (BRCA1) and ataxiatelangeictasia mutated (ATM) mutations on cellular responses to ionizing radiation. International Journal Radiation Biology, v.79, n.10, p.817-29, 2003.

MCKELVEY-MARTIN, V. J., M. H. GREEN, P. SCHMEZER, B. L. POOL-ZOBEL, M. P. DE MEO \& A. COLLINS. The single cell gel electrophoresis assay (comet assay): a European review. Mutation Research, v.28, n.1, p.47-63, 1993.

MERAJVER, S. D., T. S. FRANK, J. XU, T. M. PHAM, K. A. CALZONE, P. BENNETT-BAKER, J. CHAMBERLAIN, J. BOYD, J. E. GARBER \& F. S. COLLINS Germline BRCA1 mutations and loss of the wild-type allele in tumors from families with early onset breast and ovarian cancer. Clinical Cancer Research, v.1, n.5, p.539-44, 1995.

MIKI, Y., J. SWENSEN, D. SHATTUCK-EIDENS, P. A. FUTREAL, K. HARSHMAN, S. TAVTIGIAN, Q. LIU, C. COCHRAN, L. M. BENNETT \& W. DING A strong candidate for the breast and ovarian cancer susceptibility gene BRCA1. Science, v.266, n.5182, p.66-71, 1994.

MOZDARANI, H., B. NASIRIAN \& S. A. HAERI. In vivo gamma-rays induced initial DNA damage and the effect of famotidine in mouse leukocytes as assayed by the alkaline comet assay. Journal Radiation Research (Tokyo), v.48, n.2, p.129-34, 2007. 
MURAKAMI, D., M. F. SUZUKI, M. DA SILVA DIAS \& K. OKAZAKI. Genotoxic and cytotoxic effects of $60 \mathrm{Co}$ gamma-rays and $90 \mathrm{Sr} / 90 \mathrm{Y}$ beta-rays on Chinese hamster ovary cells (CHO-K1). Radiation and Environmental Biophysics, v.43, n.2, p.91-9, 2004.

NASCIMENTO, P. A. Avaliação do dano radioinduzido e capacidade de reparo do DNA em pacientes com câncer de mama por meio da técnica do cometa ("Single cell gel electrophoresis"). 2000. Tese (Mestrado) - Instituto de Pesquisas Energéticas Nucleares, São Paulo.

NASCIMENTO, P. A., M. A. DA SILVA, E. M. OLIVEIRA, M. F. SUZUKI \& K. OKAZAKI. Evaluation of radioinduced damage and repair capacity in blood lymphocytes of breast cancer patients. Brazilian Journal Medical and Biological Research, v.34, n.2, p.165-76, 2001.

NEWMAN, B., M. A. AUSTIN, M. LEE \& M. C. KING. Inheritance of human breast cancer: evidence for autosomal dominant transmission in high-risk families. Proceedings of the National Academy of Sciences. USA, v.85, n.9, p.3044-8, 1988.

NIEUWENHUIS, B., A. J. VAN ASSEN-BOLT, M. A. VAN WAARDE-VERHAGEN, R. H. SIJMONS, A. H. VAN DER HOUT, T. BAUCH, C. STREFFER \& H. H. KAMPINGA. BRCA1 and BRCA2 heterozygosity and repair of X-ray induced DNA damage. International Journal Radiation Biology, v.78, n.4, p.285-95, 2002.

OLIVEIRA, E. M., M. F. SUZUKI, P. A. DO NASCIMENTO, M. A. DA SILVA \& K. OKAZAKI. Evaluation of the effect of $90 \mathrm{Sr}$ beta-radiation on human blood cells by chromosome aberration and single cell gel electrophoresis (comet assay) analysis. Mutation Research, v.476, n.1-2, p.109-21, 2001

OSTLING, O. \& JOHANSON, K. J. Microelectrophoretic study of radiation-induced DNA damages in individual mammalian cells. Biochemical Biophysical Research Communications, v.123, n.1, p.291-8, 1984.

Bleomycin, in contrast to gamma irradiation, induces extreme variation of DNA strand breakage from cell to cell. International Journal Radiation Biology \& Related Studies in Physics, Chemistry \& Medicine, v.52, n.5, p.683-91, 1987.

PARSHAD, R., F. M. PRICE, V. A. BOHR, K. H. COWANS, J. A. ZUJEWSKI \& K. K. SANFORD. Deficient DNA repair capacity, a predisposing factor in breast cancer. British Journal Cancer, v.74, n.1, p.1-5, 1996.

PERERA, F. P. Environment and cancer: who are susceptible? Science, v.278, n.5340, p.1068-73, 1997.

POPANDA, O., R. EBBELER, D. TWARDELLA, I. HELMBOLD, F. GOTZES, P. SCHMEZER, H. W. THIELMANN, D. VON FOURNIER, W. HAASE, M. L. 
POPANDA, O., R. EBBELER, D. TWARDELLA, I. HELMBOLD, F. GOTZES, P. SCHMEZER, H. W. THIELMANN, D. VON FOURNIER, W. HAASE, M. L. SAUTTER-BIHL, F. WENZ, H. BARTSCH \& J. CHANG-CLAUDE. Radiationinduced DNA damage and repair in lymphocytes from breast cancer patients and their correlation with acute skin reactions to radiotherapy. International Journal Radiation Oncology Biology Physics., v.55, n.5, p.1216-25, 2003.

POUGET, J.- P. \& S. J. MATHER. General aspects of the cellular response to lowand high-LET radiation. European Journal of Nuclear Medicine and Molecular Imaging, v.28, n.4, p.541-61, 2001.

PRICE, A. The repair of ionising radiation-induced damage to DNA. Seminars in Cancer Biology, v.4, n.2, p.61-71, 1993.

RAHMAN, N. \& STRATTON, M. R. The genetics of breast cancer susceptibility. Annual Review Genetics, v.32, p.95-121, 1998.

SANKARANARAYANAN, $K$. Estimation of the genetic risks of exposure to ionizing radiation in humans: current status and emerging perspectives. Journal Radiation Research (Tokyo), v.47 Suppl B, p.B57-66, 2006.

SAVITSKY, K., A. BAR-SHIRA, S. GILAD, G. ROTMAN, Y. ZIV, L. VANAGAITE, D. A. TAGLE, S. SMITH, T. UZIEL, S. SFEZ, M. ASHKENAZI, I. PECKER, M. FRYDMAN, R. HARNIK, S. R. PATANJALI, A. SIMMONS, G. A. CLINES, A. SARTIEL, R. A. GATTI, L. CHESSA, O. SANAL, M. F. LAVIN, N. G. JASPERS, A. M. TAYLOR, C. F. ARLETT, T. MIKI, S. M. WEISSMAN, M. LOVETT, F. S. COLLINS \& Y. SHILOH. A single ataxia telangiectasia gene with a product similar to PI-3 kinase. Science, v.268, n.5218, p.1749-53, 1995.

SCHMID, W. The micronucleus test. Mutation Research, v.31, n.1, p.9-15, 1975.

SCHMIDBERGER, H., R. M. HERMANN, C. F. HESS \& G. EMONS. Interactions between radiation and endocrine therapy in breast cancer. Endocrine Related Cancer, v.10, n.3, p.375-88, 2003.

SCOTT, D., J. B. BARBER, E. L. LEVINE, W. BURRILL \& S. A. ROBERTS. Radiation-induced micronucleus induction in lymphocytes identifies a high frequency of radiosensitive cases among breast cancer patients: a test for predisposition? British Journal Cancer, v.77, n.4, p.614-20, 1998.

SCULLY, R., J. CHEN, A. PLUG, Y. XIAO, D. WEAVER, J. FEUNTEUN, T. ASHLEY \& D. M. LIVINGSTON. Association of BRCA1 with Rad51 in mitotic and meiotic cells. Cell, v.88, n.2, p.265-75, 1997.

SILES, E., M. VILLALOBOS, M. T. VALENZUELA, M. I. NUNEZ, A. GORDON, T. J. MCMILLAN, V. PEDRAZA \& J. M. RUIZ DE ALMODOVAR. Relationship between p53 status and radiosensitivity in human tumour cell lines. British Journal Cancer, v.73, n.5, p.581-8, 1996. 
SINGH, N. P., M. T. MCCOY, R. R. TICE \& E. L. SCHNEIDER. A simple technique for quantitation of low levels of DNA damage in individual cells. Experimental Cell Research, v.175, n.1, p.184-91, 1988.

SPEIT, G. \& HARTMANN, A. The comet assay (single-cell gel test). A sensitive genotoxicity test for the detection of DNA damage and repair. Methods in Molecular Biology, v.113, p.203-12, 1999.

STARCEVIC, S. L., N. M. DIOTTE, K. L. ZUKOWSKI, M. J. CAMERON \& R. F. NOVAK. Oxidative DNA damage and repair in a cell lineage model of human proliferative breast disease (PBD). The Journal of toxicological sciences, v.75, n.1, p.74-81, 2003.

SURRALLES, J., E. CARBONELL, R. MARCOS, F. DEGRASSI, A. ANTOCCIA \& C. TANZARELLA. A collaborative study on the improvement of the micronucleus test in cultured human lymphocytes. Mutagenesis, v.7, n.6, p.407-10, 1992.

SVEJSTRUP, J. Q. Mechanisms of transcription-coupled DNA repair. Nature Reviews Molecular Cell Biology, v.3, n.1, p.21-9, 2002.

TAVTIGIAN, S. V., J. SIMARD, J. ROMMENS, F. COUCH, D. SHATTUCKEIDENS, S. NEUHAUSEN, S. MERAJVER, S. THORLACIUS, K. OFFIT, D. STOPPA-LYONNET, C. BELANGER, R. BELL, S. BERRY, R. BOGDEN, Q. CHEN, T. DAVIS, M. DUMONT, C. FRYE, T. HATTIER, S. JAMMULAPATI, T. JANECKI, P. JIANG, R. KEHRER, J. F. LEBLANC, J. T. MITCHELL, J. MCARTHUR-MORRISON, K. NGUYEN, Y. PENG, C. SAMSON, M. SCHROEDER, S. C. SNYDER, L. STEELE, M. STRINGFELLOW, C. STROUP, B. SWEDLUND, J. SWENSE, D. TENG, A. THOMAS, T. TRAN, M. TRANCHANT, J. WEAVER-FELDHAUS, A. K. WONG, H. SHIZUYA, J. E. EYFJORD, L. CANNONALBRIGHT, F. LABRIE, M. H. SKOLNICK, B. WEBER, A. KAMB \& D. E. GOLDGAR. The complete BRCA2 gene and mutations in chromosome 13q-linked kindreds. Nature Genetics, v.12, n.3, p.333-7, 1996.

TAYLOR, E. M. \& LEHMANN, A. R. Conservation of eukaryotic DNA repair mechanisms. International Journal Radiation Biology, v.74, n.3, p.277-86, 1998.

THOMPSON, L. H. \& SCHILD, D. Recombinational DNA repair and human disease. Mutation Research, v.509, n.1-2, p.49-78, 2002.

TICE, R. R. \& STRAUSS, G. H. The single cell gel electrophoresis/comet assay: a potential tool for detecting radiation-induced DNA damage in humans. Stem Cells, v.13 Suppl 1, p.207-14, 1995.

TOKUNAGA, M., C. E. LAND, T. YAMAMOTO, M. ASANO, S. TOKUOKA, $H$. EZAKI \& I. NISHIMORI. Incidence of female breast cancer among atomic bomb 
survivors, Hiroshima and Nagasaki, 1950-1980. Radiation Research, v.112, n.2, p.243-72, 1987.

TRENZ, K., S. LUGOWSKI, U. JAHRSDORFER, S. JAINTA, W. VOGEL \& G. SPEIT. Enhanced sensitivity of peripheral blood lymphocytes from women carrying a BRCA1 mutation towards the mutagenic effects of various cytostatics. Mutation Research, v.544, n.2-3, p.279-88, 2003.

Radiosensitivity of lymphoblastoid cell lines with a heterozygous BRCA1 mutation is not detected by the comet assay and pulsed field gel electrophoresis. Mutagenesis, v.20, n.2, p.131-7, 2005.

VENITT, S. Mechanisms of carcinogenesis and individual susceptibility to cancer. Clinical Chemistry, v.40, n.7 pt 2, p.1421-5, 1994.

WANG, H., Z. C. ZENG, T. A. BUI, S. J. DIBIASE, W. QIN, F. XIA, S. N. POWELL $\&$ G. ILIAKIS. Nonhomologous end-joining of ionizing radiation-induced DNA double-stranded breaks in human tumor cells deficient in BRCA1 or BRCA2. Cancer Research, v.61, n.1, p.270-7, 2001.

WHITAKER, S. J., S. N. POWELL \& T. J. MCMILLAN. Molecular assays of radiation-induced DNA damage. European Journal of Cancer, v.27, n. 7, p.9228, 1991.

WHO. National Cancer Control Programmes. Policies and Managerial Guidelines. Genebra, 2002.

WOOSTER, R., S. L. NEUHAUSEN, J. MANGION, Y. QUIRK, D. FORD, N. COLLINS, K. NGUYEN, S. SEAL, T. TRAN \& D. AVERILL Localization of a breast cancer susceptibility gene, BRCA2, to chromosome 13q12-13. Science, v.265, n.5181, p.2088 -90, 1994.

XIA, F., D. G. TAGHIAN, J. S. DEFRANK, Z. C. ZENG, H. WILLERS, G. ILIAKIS \& S. N. POWELL. Deficiency of human BRCA2 leads to impaired homologous recombination but maintains normal nonhomologous end joining. Proceedings of the National Academy of Sciences, USA, v.98, n.15, p.8644-9, 2001.

ZAHA, A. F., H. B. \& PASSAGLIA, L. M. P. Biologia Molecular Básica Porto Alegre: Mercado Aberto, 2003.

ZHAN, Q. Gadd45a, a p53- and BRCA1-regulated stress protein, in cellular response to DNA damage. Mutation Research, v.569, n.1-2, p.133-43, 2005. 